\title{
A computational model of the hypothalamic - pituitary - gonadal axis in female fathead minnows (Pimephales promelas) exposed to $17 \alpha$-ethynylestradiol and $17 \beta$-trenbolone
}

Zhenhong Li ${ }^{1}$, Kevin J Kroll ${ }^{2}$, Kathleen M Jensen ${ }^{3}$, Daniel L Villeneuve ${ }^{3}$, Gerald T Ankley ${ }^{3}$, Jayne V Brian ${ }^{4}$, María S Sepúlveda ${ }^{5}$, Edward F Orlando ${ }^{6}$, James M Lazorchak ${ }^{7}$, Mitchell Kostich7, Brandon Armstrong ${ }^{8}$, Nancy D Denslow ${ }^{2}$ and Karen $\mathrm{H}$ Watanabe ${ }^{1 *}$

\begin{abstract}
Background: Endocrine disrupting chemicals (e.g., estrogens, androgens and their mimics) are known to affect reproduction in fish. $17 \alpha$-ethynylestradiol is a synthetic estrogen used in birth control pills. $17 \beta$-trenbolone is a relatively stable metabolite of trenbolone acetate, a synthetic androgen used as a growth promoter in livestock. Both $17 \alpha$-ethynylestradiol and $17 \beta$-trenbolone have been found in the aquatic environment and affect fish reproduction. In this study, we developed a physiologically-based computational model for female fathead minnows (FHM, Pimephales promelas), a small fish species used in ecotoxicology, to simulate how estrogens (i.e., $17 \alpha$-ethynylestradiol) or androgens (i.e., $17 \beta$-trenbolone) affect reproductive endpoints such as plasma concentrations of steroid hormones (e.g., 17ß-estradiol and testosterone) and vitellogenin (a precursor to egg yolk proteins).

Results: Using Markov Chain Monte Carlo simulations, the model was calibrated with data from unexposed, $17 \alpha$ ethynylestradiol-exposed, and $17 \beta$-trenbolone-exposed FHMs. Four Markov chains were simulated, and the chains for each calibrated model parameter (26 in total) converged within 20,000 iterations. With the converged parameter values, we evaluated the model's predictive ability by simulating a variety of independent experimental data. The model predictions agreed with the experimental data well.

Conclusions: The physiologically-based computational model represents the hypothalamic-pituitary-gonadal axis in adult female FHM robustly. The model is useful to estimate how estrogens (e.g., 17 1 -ethynylestradiol) or androgens (e.g., 17 3 -trenbolone) affect plasma concentrations of $17 \beta$-estradiol, testosterone and vitellogenin, which are important determinants of fecundity in fish.
\end{abstract}

\section{Background}

In vertebrates, such as fish, the hypothalamic-pituitarygonadal (HPG) axis controls reproductive processes through a variety of hormones which act on target tissues directly or indirectly $[1,2]$. The HPG axis can be altered by endocrine disrupting chemicals (EDCs) in the aquatic environment which mimic endogenous

\footnotetext{
* Correspondence: watanabe@ebs.ogi.edu

'Division of Environmental and Biomolecular Systems, Oregon Health \&

Science University, Beaverton, OR, 97006, USA

Full list of author information is available at the end of the article
}

hormones, alter their concentrations, or block their actions [3].

In recent years, many scientific studies have been conducted to study reproductive effects of EDCs in fathead minnow (FHM, Pimephales promelas), a model small fish species used in ecotoxicology [4-6]. Two EDCs, $17 \alpha$-ethynylestradiol and $17 \beta$-trenbolone, have been widely studied as model estrogens and androgens, respectively [7-11]. Both compounds also are environmentally relevant contaminants.

\section{C) Biomed Central}

(c) $2011 \mathrm{Li}$ et al; licensee BioMed Central Ltd. This is an Open Access article distributed under the terms of the Creative Commons Attribution License (http://creativecommons.org/licenses/by/2.0), which permits unrestricted use, distribution, and reproduction in any medium, provided the original work is properly cited. 
$17 \alpha$-ethynylestradiol $\left(\mathrm{EE}_{2}\right)$, a synthetic estrogen used in birth control pills, enters the environment mainly through effluents from wastewater treatment facilities. The reported median $\mathrm{EE}_{2}$ concentration in the aquatic environment varies from $<0.5$ to $15 \mathrm{ng} / \mathrm{L}$ [12]. Due in part to its high binding affinity for estrogen receptor (ER) [13-15], EE $E_{2}$ affects the HPG axis in FHM at environmentally relevant concentrations. Exposure to $\mathrm{EE}_{2}$ has been shown to result in altered hormone profiles, and increased vitellogenin (VTG, a precursor of egg yolk proteins) levels in both male and female FHMs [16]. In addition, a seven-year, whole-lake experiment conducted in Canada [17] showed that chronic exposure of FHMs to $5-6 \mathrm{ng} \mathrm{EE}_{2} / \mathrm{L}$ led to near-extinction of this species from the lake.

$17 \beta$-trenbolone (TB) is a relatively stable metabolic product of trenbolone acetate, a synthetic androgen used as a growth promoter in livestock (e.g., cattle). TB enters the environment mainly as runoff from livestock feedlots. Schiffer et al. [18] reported that the TB concentration in effluents of solid cattle dung was around 19 ng/L. Durhan et al. [19] studied a cattle feedlot located in southwest central Ohio, and reported that the TB concentration in feedlot discharge was between 10 and $20 \mathrm{ng} / \mathrm{L}$. TB has a high binding affinity for the androgen receptor (AR). Water exposure to $\mathrm{TB}$ at concentrations similar to those found in the environment decreases egg production in FHM in conjunction with changes in plasma concentrations of $17 \beta$-estradiol $\left(\mathrm{E}_{2}\right)$, testosterone (T), and VTG in females [7]. Interestingly, relationships between TB water exposure concentrations and plasma $\mathrm{E}_{2}$, T and VTG concentrations were not monotonic, but were "U-shaped" [7].

To better understand the dynamics of the HPG axis in female FHMs and to facilitate the evaluation of adverse outcomes on reproduction from both estrogenic and androgenic EDC exposure, we developed a physiologically based computational model to simulate key reproductive endpoints, such as plasma concentrations of $E_{2}$, $\mathrm{T}$, and VTG, in adult female FHMs. The model simulates absorption, distribution, and elimination of TB and $\mathrm{EE}_{2}$ by incorporating salient physiological characteristics of FHMs and modelling biochemical pathways and reactions mathematically. This model is a first step toward predicting adverse outcomes on reproduction, which is an important component of ecological risk assessment. It robustly links $\mathrm{TB}$ and $\mathrm{EE}_{2}$ exposure to plasma steroid hormone and VTG concentrations, which can then be used to predict effects on fecundity. Though this model does not simulate oocyte growth dynamics to predict fecundity, it can be integrated with an oocyte growth dynamics model to do so. To our knowledge, it is the first physiologically based model capable of simulating exposure to a mixture of an estrogen and an androgen.

\section{Methods}

\section{Model Formulation}

We developed the HPG axis model for female FHM by modifying a computational model for male FHM described by Watanabe et al. [20]. The model simulates time continuously, but it does not have a seasonal component. In the following, we mainly focus on the unique formulations and/or assumptions in this model for female FHMs.

The model for female FHMs contains six tissue compartments which represent organs or tissues important for absorption, distribution, metabolism, and elimination of exogenous and endogenous chemicals of interest (Figure 1). The six compartments are gill, brain, gonad, liver, venous blood and "other". In the arterial blood, the concentrations of both free and bound chemicals are equal to those in the venous blood compartment, unless a chemical(s) enters the body through a water exposure. As a result, we did not count arterial blood as an independent compartment. Based upon a mass balance for each chemical of interest, a set of coupled ordinary differential equations were formulated in each compartment following the principles of physiologically based pharmacokinetic modeling. A detailed description of the differential equations can be found in Additional File 1: Differential equations used in the HPG axis model.

In the brain, gonad, and liver compartments, we simulated both ER and AR dynamics. The AR component was not included in the model for male FHM published by Watanabe et al. [20]. ER binds estrogens (e.g., $\mathrm{E}_{2}$ and $E_{2}$ ), and bound ER affects the production of VTG. AR binds androgens (e.g., T and TB), and subsequently regulates biochemical processes such as the production of gonadotropins [21]. A general mathematical formulation of ligand-receptor binding is shown in Equation 1.

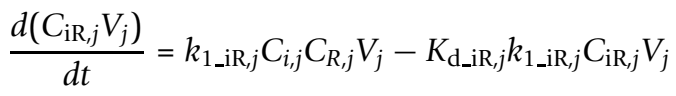

where, $C_{\mathrm{iR}, j}(\mathrm{nmol} / \mathrm{L})$ is the concentration of compound $i$ (e.g. T, TB, $\mathrm{E}_{2}$ and $\mathrm{EE}_{2}$ ) bound to its receptor in compartment $j$ (e.g. brain, liver, gonad, and venous blood) ; $V_{j}(\mathrm{~L})$ is the volume of compartment $j ; k_{1 \_\mathrm{iR}, j}$ $(\mathrm{L} / \mathrm{nmol} / \mathrm{hr})$ is the association rate constant of compound $i$ with its receptor in compartment $j ; C_{i, j}(\mathrm{nmol} /$ $\mathrm{L}$ ) is the concentration of free compound $i$ in compartment $j ; C_{R, j}(\mathrm{nmol} / \mathrm{L})$ is the concentration of unbound receptor of compound $i$ in compartment $j ; K_{\mathrm{d}_{-} \mathrm{iR}, j}$ $(\mathrm{nmol} / \mathrm{L})$ is the equilibrium dissociation constant of compound $i$ with its receptor in compartment $j$.

Gill

In the gill compartment, we did not simulate any production of proteins (e.g., VTG), hormones (e.g., 


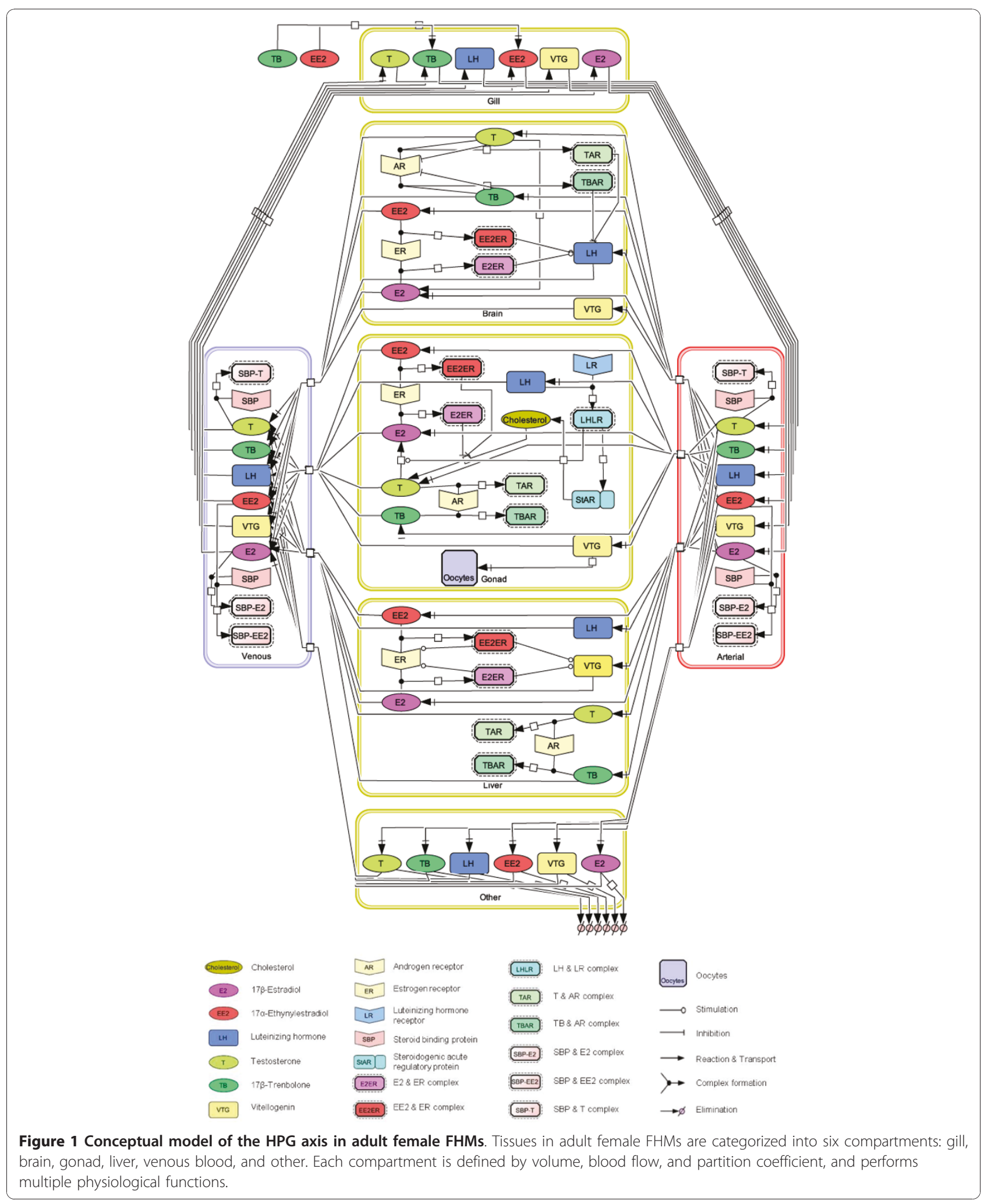


luteinizing hormone, LH), or hormone receptors (e.g, ER and AR). ER mRNA is present in FHM gills, however, we did not simulate ER in the gill compartment because the gill expression of ER is very low compared to other tissues [22]. We simulated the exposure of female FHMs to $\mathrm{TB}$ and/or $\mathrm{EE}_{2}$ in water, and the gill compartment is where the exogenous chemicals are absorbed. The concentration of each chemical in exposure water was represented as a function of time. Then, equilibrium partitioning was assumed, and the FHM arterial blood concentration was calculated from the water concentration using an equilibrium partition coefficient assigned for each chemical (Equation 2). In addition, we assumed that the gill compartment did not accumulate any chemical(s).

$$
\mathrm{CArt}_{i}=\frac{\mathrm{FW}_{\text {gil }} \times C_{i, \mathrm{H} 20}+F_{\mathrm{car}} \times \mathrm{CVen}_{i}}{\frac{\mathrm{FW}_{\mathrm{gil}}}{\lambda_{i, \mathrm{bld}}}+F_{\mathrm{car}}}
$$

where, $\mathrm{CArt}_{i}(\mathrm{nmol} / \mathrm{L})$ is the concentration of exogenous chemical $i$ in arterial blood; $\mathrm{FW}_{\mathrm{gil}}(\mathrm{L} / \mathrm{hr})$ is the volumetric flow rate of water through the gills; $C_{i, \mathrm{H} 2 \mathrm{O}}$ $(\mathrm{nmol} / \mathrm{L})$ is the concentration of exogenous chemical $i$ (e.g. $\mathrm{TB}$ and $\mathrm{EE}_{2}$ ) in exposure water as a function of time; $F_{\text {car }}(\mathrm{L} / \mathrm{hr})$ is cardiac output; and $\mathrm{CVen}_{i}(\mathrm{nmol} / \mathrm{L})$ is the concentration of exogenous chemical $i$ in venous blood; $\lambda_{i}$, bld is the partition coefficient for exogenous chemical $i$ between blood and water. Partition coefficients are often determined experimentally, but when a measured or model-estimated value is unavailable, we calibrate it to fit the experimental data.

\section{Brain}

In the brain compartment, three key assumptions were made: (i) the down-regulation of LH (gonadotropin II) synthesis by bound AR [23,24]; (ii) the up-regulation of LH synthesis by bound ER [25]; and (iii) the down-regulation of AR synthesis by free androgens [26,27].

In the brain, androgens have a negative feedback on the synthesis and release of gonadotropin releasing hormone (GnRH) [23], which in turn controls the synthesis of gonadotropins. To investigate how androgens may regulate $\mathrm{GnRH}$, we searched for an androgen response element (ARE) in the promoter regions of gnrh genes. Due to a lack of information on gene promoter sequences in FHM, we conducted the search in zebrafish (Danio rerio), a cyprinid fish closely related to FHM. We found that gnrh promoters contain several ARE half sites (tgttct) [24]. Thus, we postulated that androgens have a negative control on GnRH synthesis mainly through bound AR. However, we did not have any measurements of GnRH in FHM and GnRH was not included in the model, so we formulated a downregulation of LH synthesis by bound AR in the model.
Second, we assumed an up-regulation of LH synthesis by bound ER in the brain compartment. This assumption was based upon observations of estrogen response elements (EREs) in the promoter region of the lh gene and reports of estrogen-stimulated LH production in fish [25]. Equation 3 describes the LH production rate in the brain compartment as a function of bound $A R$ and ER. In the equation, $P_{\mathrm{LH}}$, brn $(\mathrm{nmol} / \mathrm{hr})$ is the production rate of $\mathrm{LH}$ in brain; $P_{\mathrm{b} \_\mathrm{LH}}$, brn $(\mathrm{nmol} / \mathrm{hr})$ is the background production rate of LH in brain, which was formulated as a diurnal cycle; $C_{\mathrm{ER} \_ \text {bd, brn }}(\mathrm{nmol} / \mathrm{L})$ is the total concentration of bound ER in brain, which equals the sum of $E_{2}-$ and $E_{2}$ - bound $E R$ concentrations; $\rho_{\mathrm{u} \_ \text {LH, brn }}(\mathrm{nmol} / \mathrm{L})$ is an induction factor for $\mathrm{LH}$ production by bound ER; $C_{\mathrm{AR} \_ \text {bd, brn }}(\mathrm{nmol} / \mathrm{L})$ is the total concentration of bound $A R$ in brain, which equals the sum of T- and TB- bound AR concentrations; $\rho_{\mathrm{d} \_\mathrm{LH}}$, brn $(\mathrm{nmol} / \mathrm{L})$ is a factor for inhibition of $\mathrm{LH}$ production by bound AR.

$$
P_{\mathrm{LH}, \mathrm{brn}}=P_{\mathrm{b} \_\mathrm{LH}, \mathrm{brn}} \times \frac{1+\frac{C_{\mathrm{ER} \_ \text {bd,brn }}}{\rho_{\mathrm{u} \_ \text {LH,brn }}}}{1+\frac{C_{\mathrm{AR} \_ \text {bd,brn }}}{\rho_{\mathrm{d} \_\mathrm{LH}, \mathrm{brn}}}}
$$

The brain compartment is also very important for the regulation of AR production [26,27]. In mammals (e.g. rats, mice, and human), AR mRNA in brain is downregulated by androgens, such as $\mathrm{T}$ and dihydrotestosterone [26,27], though little is known about the corresponding mechanisms. We searched for AREs in the promoter region of the ar gene in zebrafish, but did not find any match. Hence, we postulated that the down-regulation of AR mRNA by androgens is associated with a non-genomic pathway [28], or associated with cell factors other than the soluble AR simulated in our model [29]. Thus, we assumed a down-regulation of AR production by free androgens in the brain compartment. When ARs are produced, some bind androgens, some remain unbound, and others degrade. Based upon a mass balance for free AR, Equation 4 describes the processes of AR production, association and dissociation with $\mathrm{T}$ or $\mathrm{TB}$, and degradation.

$$
\begin{aligned}
& \frac{d\left(C_{\mathrm{AR} \_ \text {free,brn }}\right)}{d t}=\frac{\mathrm{Pbg}_{\mathrm{AR}, \mathrm{brn}}}{1+\frac{\left(C_{T, \mathrm{brn}}+C_{\mathrm{TB}, \mathrm{brn}}\right)}{K_{\mathrm{AR}, \mathrm{brn}}}}-\left(k_{1-\mathrm{TAR}, \mathrm{brn}} \times C_{T, \mathrm{brn}} \times C_{\mathrm{AR} \text { free, brn }}\right.
\end{aligned}
$$

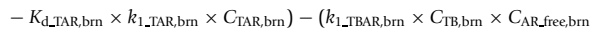

$$
\begin{aligned}
& \left.-K_{\mathrm{d}_{\mathrm{A}} \mathrm{TBAR}, \mathrm{brn}} \times k_{1_{-} \mathrm{TBAR}, \mathrm{bm}} \times \mathrm{C}_{\mathrm{TBAR}, \mathrm{brn}}\right)-k_{\mathrm{e} A \mathrm{AR}, \mathrm{brn}} \times \mathrm{C}_{\mathrm{AR} \_ \text {free, brm }}
\end{aligned}
$$

where, $C_{\mathrm{AR}_{-} \text {free, brn }}(\mathrm{nmol} / \mathrm{L})$ is the free AR concentration in brain; $\mathrm{Pbg}_{\mathrm{AR}}$, brn $(\mathrm{nmol} / \mathrm{L} / \mathrm{hr})$ is the background production rate of AR in brain; $C_{T}$, brn $(\mathrm{nmol} / \mathrm{L})$ is the free $\mathrm{T}$ concentration in brain; $C_{\mathrm{TB}}$, brn $(\mathrm{nmol} / \mathrm{L})$ is the free TB concentration in brain; $K_{\mathrm{AR}}$, brn $(\mathrm{nmol} / \mathrm{L})$ is an inhibition rate constant for AR production by free $\mathrm{T}$ and TB; $k_{1 \_\mathrm{TAR}}$, brn $(\mathrm{L} / \mathrm{nmol} / \mathrm{hr})$ is the association rate 
constant for $\mathrm{T}$ and $\mathrm{AR}$; $\mathrm{K}_{\mathrm{d}_{-} \mathrm{TAR}}$, brn $(\mathrm{nmol} / \mathrm{L})$ is the dissociation rate constant for $\mathrm{T}$ bound to $\mathrm{AR} ; C_{\mathrm{TAR}}$, brn $(\mathrm{nmol} / \mathrm{L})$ is the concentration of the T-AR complex in brain; $k_{1}$ TBAR, brn $(\mathrm{L} / \mathrm{nmol} / \mathrm{hr})$ is the association rate of

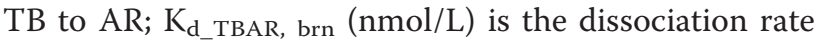
constant for TB bound to AR; $C_{\mathrm{TBAR}}$ brn $(\mathrm{nmol} / \mathrm{L})$ is the concentration of the TB-AR complex in brain; and $k_{\text {e_AR, brn }}(1 / \mathrm{hr})$ is the elimination rate for free AR. We included the inhibition of LH by bound AR and the inhibition of AR by free androgens to account for the $U$-shaped dose-response curves for plasma $E_{2}, T$ and VTG concentrations observed in female FHMs exposed to TB [7]. These assumptions and mathematical formulations provided a robust fit to the available data [7]. An alternate formulation based upon brain AR and gonad AR with different binding affinities was tried first. However, because of a lack of parameter information and evidence for the biological mechanism, we abandoned this approach for the present version. The present model formulation makes more sense biologically, and is simpler.

\section{Gonad}

In the gonad compartment, modifications to the model formulations for male FHMs include (i) absorption of VTG into oocytes; and (ii) up-regulation of $\mathrm{E}_{2}$ production by bound LH. The absorption of VTG into oocytes was formulated as a first order kinetic process. VTG is synthesized in the liver [30], and circulates to the gonads where it is taken up via receptor-mediated endocytosis into oocytes, and then processed into yolk proteins [31]. Although the molecular mechanism of VTG uptake is known, we did not have data to describe this process quantitatively. As a result, a first order kinetic equation with an assumed first order rate constant was formulated to represent the process (Equation 5).

$$
R_{\mathrm{VTG}, \text { gon }}=k_{\mathrm{VTG} \text {,gon }} \times C_{\mathrm{VTG} \text {,gon }} \times V_{\text {gon }}
$$

where, $R_{\mathrm{VTG}}$, gon $(\mathrm{nmol} / \mathrm{hr}$ ) is the absorption rate of VTG into oocytes in the gonad compartment; $k_{\mathrm{VTG}}$, gon $(1 / \mathrm{hr})$ is the absorption rate constant for VTG into oocytes in the gonad compartment; $C_{\mathrm{VTG}}$, gon $(\mathrm{nmol} / \mathrm{L})$ is the concentration of VTG in the gonad compartment; and $V_{\text {gon }}(1 / \mathrm{L})$ is the volume of the gonad compartment.

Secondly, we simulated an up-regulation of $E_{2}$ production by bound $\mathrm{LH}$ in the gonad compartment. It was observed that LH stimulates the activity and gene expression of aromatase in the gonads of teleosts [32]. In our model, we formulated the regulation of $\mathrm{E}_{2}$ production as being proportional to the concentration of bound LH in the gonad compartment (Equation 6).

$$
P_{\mathrm{E} 2 \text {,gon }}=\frac{\rho_{\mathrm{E} 2 \text { LLHLR,gon }} \times C_{\mathrm{LHLR,gon}} \times \mathrm{Vmax}_{\text {aro,gon }} \times C_{T, \text { gon }}}{\mathrm{Km}_{\mathrm{aro} \text {,gon }}+C_{T, \text { gon }}}
$$

where, $P_{\mathrm{E} 2 \text {, gon }}(\mathrm{nmol} / \mathrm{hr})$ is the rate of $\mathrm{E}_{2}$ production; $\rho_{\text {E2_LHLR, gon }}(\mathrm{L} / \mathrm{nmol})$ is an induction factor of $E_{2}$ production by bound LH; $C_{\mathrm{LHLR}}$, gon $(\mathrm{nmol} / \mathrm{L})$ is the concentration of bound $\mathrm{LH} ; \mathrm{Vmax}_{\text {aro, gon }}(\mathrm{nmol} / \mathrm{hr}$ ) is the maximum rate of $\mathrm{E}_{2}$ production by gonad aromatase; $\mathrm{Km}_{\text {aro, gon }}(\mathrm{nmol} / \mathrm{L})$ is the Michaelis-Menten constant for gonad aromatase; $C_{T}$, gon $(\mathrm{nmol} / \mathrm{L})$ is the concentration of $\mathrm{T}$.

Liver

In the liver compartment, formulations including ER auto-regulation and bound-ER-stimulated VTG production are the same as those described by Watanabe et al. [20], except that we added ligand-receptor binding of $\mathrm{T}$ and TB to the AR.

\section{Venous blood}

Besides $\mathrm{E}_{2}$ and $\mathrm{T}$, we simulated the association and dissociation processes of $\mathrm{EE}_{2}$ to steroid-binding proteins (SBPs) in the venous blood compartment. There is contradictory information about the binding affinities of $\mathrm{EE}_{2}$ to SBPs in fish. Compared to $\mathrm{E}_{2}$, some fish species such as channel catfish (Ictalurus punctatus) and zebrafish (Danio rerio) have high binding affinity of $\mathrm{EE}_{2}$ to SBPs [33,34], while other fish species such as Arctic charr (Salvelinus alpinus) have a low binding affinity [35]. To date, binding affinity measurements of $\mathrm{EE}_{2}$ to SBPs in FHM have not been made. Watanabe et al. [20] did not include the binding process of $\mathrm{EE}_{2}$ to SBPs in blood. In their modelling work for male FHMs, the total concentration of SBPs was assumed to be $20 \mathrm{nmol} / \mathrm{L}$ based upon a measurement in human males [36]. Such a low value has little effect on free plasma $\mathrm{EE}_{2}$ concentration or model performance. However, in our model for female FHMs, we assumed the total concentration of SBPs to be $400 \mathrm{nmol} / \mathrm{L}[36,37]$ based upon SBP measurements in female spotted seatrout (Cynoscion nebulosus) [37] and in human females [36]. Consequently, a large amount of $\mathrm{EE}_{2}$ could be bound by SBPs in blood, which would affect the total concentration of $\mathrm{EE}_{2}$ in the plasma. Therefore, we included the binding process of $\mathrm{EE}_{2}$ to SBPs in this model, and formulated it using Equation 1.

\section{Other}

In our model, the 'Other' compartment is where elimination of exogenous and endogenous chemicals and proteins occur. Besides $E_{2}, E_{2}, T, V T G$, and $L H$ (included in Watanabe et al. [20]), we added a first order kinetic equation to describe the elimination of $\mathrm{TB}$, and the first order elimination rate constant was assumed to be the same as that of $\mathrm{EE}_{2}$ (Equation 7).

$$
R_{\mathrm{TB}, \mathrm{oth}}=k_{\mathrm{e} \_\mathrm{TB}, \mathrm{oth}} \times C_{\mathrm{TB}, \mathrm{oth}} \times V_{\text {oth }}
$$

where $R_{\mathrm{TB}}$, oth $(\mathrm{nmol} / \mathrm{hr})$ is the elimination rate of TB in the Other compartment; $k_{\mathrm{e}-\mathrm{TB}}$, oth $(1 / \mathrm{hr})$ is the 
elimination rate constant for $\mathrm{TB}$ in the Other compartment; $C_{\mathrm{TB}}$, oth $(\mathrm{nmol} / \mathrm{L})$ is the concentration of $\mathrm{TB}$ in the Other compartment; and $V_{\text {oth }}(1 / \mathrm{L})$ is the volume of the Other compartment.

\section{Experimental Data}

To calibrate model parameters and to evaluate model predictions, we used data from unexposed, TB-exposed, and $\mathrm{EE}_{2}$-exposed adult female FHMs from 18 different studies. All studies were conducted with sexually mature (five to seven month old) female FHMs. Chemical exposures were conducted in the laboratory under optimal conditions for FHM reproduction. For example, the temperature was $25^{\circ} \mathrm{C}$, photoperiod was $16 / 8 \mathrm{hr}$ (light to dark), and food was not limited. Under such conditions, FHMs can remain in reproductive condition and spawn year around. For each fish, physiological parameters, including body weight (BW), gonadosomatic index (GSI), and hepatosomatic index (HSI), were input into the model. For all experimental data used in model calibration or validation, when any measurements of $\mathrm{BW}$, GSI, or HSI were missing, we used the medians of measured BW, GSI, or HSI, respectively [38]. Ideally, if all experimental data had been available when we started to develop the model in 2006, we would have randomly selected a subset of data from each experiment for model calibration and used the remainder for model evaluation. However, several of the experimental studies were conducted while the model was being developed. Thus, we used data as they became available. The following summarizes the experimental data and how the data were used.

The reproductive endpoint data in unexposed (control) adult female FHMs were obtained from an earlier paper by Watanabe et al. [38]. In a total of 170 female FHMs, the data include measurements of plasma $E_{2}, T$, and VTG concentrations; all measurements were made in some fish, and in others only a subset of endpoints (e.g., plasma $\mathrm{E}_{2}$ and VTG concentrations) were measured. We randomly split the data; the first 75 records were used to calibrate our model; the remaining 95 records were used in model validation.

Experimental data from TB-exposed adult female FHMs were obtained from three studies: (i) a flowthrough water exposure to nominal concentrations of $0.005,0.05,0.5,5.0$, and $50 \mu \mathrm{g} \mathrm{TB} / \mathrm{L}$ for 21 days by Ankley et al. [7]; (ii) a static exposure to nominal concentrations of $0.05,0.5,5 \mu \mathrm{g} \mathrm{TB} / \mathrm{L}$ for 48 hours by Garcia-Reyero et al. [39]; and (iii) a flow-through water exposure to nominal concentrations of 0.05 and $0.5 \mu \mathrm{g}$ $\mathrm{TB} / \mathrm{L}$ in adult female FHMs for eight days, followed by an eight-day depuration described by Ekman et al. [40]. In Ankley et al. [7], 12 female FHMs were exposed in each treatment group. On the $21^{\text {st }}$ day of exposure, all
FHMs were sacrificed; plasma concentrations of $E_{2}, T$, and VTG were measured in each fish. In Garcia-Reyero et al. [39] eight FHMs were exposed in each treatment group. After a 48-hour exposure, the fish were sacrificed. For each treatment group, plasma $E_{2}$ concentrations were measured in each of four fish, and plasma VTG concentrations were measured in each of the four remaining fish. The concentrations of VTG and $E_{2}$ were not measured in the same fish because Dr. Orlando's laboratory measured $E_{2}$ and Dr. Denslow's laboratory measured VTG. In Ekman et al. [40], 64 FHMs were exposed to TB in each treatment group. On the $1^{\text {st }}, 2^{\text {nd }}$, $4^{\text {th }}$, and $8^{\text {th }}$ day of exposure and the $1^{\text {st }}, 2^{\text {nd }}, 4^{\text {th }}$, and $8^{\text {th }}$ day of depuration (test days 9, 10, 12, and 16), for each treatment group, eight FHMs were sacrificed to measure plasma $E_{2}$ and VTG concentrations in each fish. Data from Ankley et al. [7] were used to calibrate our model, and data from Garcia-Reyero et al. [39] and Ekman et al. [40] were used to evaluate our model predictions.

VTG plasma concentrations in adult female FHMs exposed to $\mathrm{EE}_{2}$ were obtained from three studies: (i) a flow-through water exposure to nominal concentrations of 10 or $100 \mathrm{ng} \mathrm{EE}_{2} / \mathrm{L}$ in adult female FHMs for eight days, followed by an eight-day depuration [41]; (ii) a flow-through water exposure to a nominal concentration

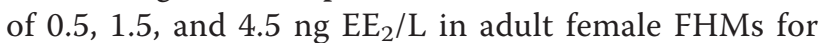
21 days by Lazorchak et al. [42]; and (iii) a flow-through water exposure to a nominal concentration of $1.5 \mathrm{ng}$ $\mathrm{EE}_{2} / \mathrm{L}$ in adult female FHMs for 21 days by Brian et al. [43]. In Ekman et al. [41], for each treatment group and each sampling time, eight FHMs were sacrificed to measure plasma VTG concentration in each fish. Sampling occurred on the $1^{\text {st }}, 4^{\text {th }}$, and $8^{\text {th }}$ day of exposure to $E_{2}$, and the $8^{\text {th }}$ day of $\mathrm{EE}_{2}$ depuration (test day 16). In Lazorchak et al. [42], 28 FHMs in each of the treatment

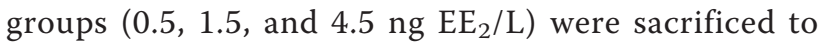
measure plasma VTG concentration in each fish on the $21^{\text {st }}$ day. In Brian et al. [43], four FHMs were sacrificed to measure plasma VTG concentration in each fish on

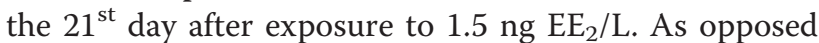
to the three $\mathrm{TB}$ and two $\mathrm{EE}_{2}$ studies which did not use carrier solvents, Brian et al. [39] used N, N-dimethylformamide, DMF, as a chemical carrier for $\mathrm{EE}_{2}$. Data from Ekman et al. [41] were used to calibrate our model, and data from Lazorchak et al. [42], and Brian et al. [43] were used to evaluate our model predictions.

\section{Model Calibration}

In total, our model contains 123 input parameters, such as volume and blood flow rates of each compartment, chemical equilibrium partition coefficients, ligand-receptor association and dissociation rate constants, and kinetic rate constants for each biochemical reaction. The parameters were fixed with known values, or 
calibrated using experimental data collected in adult female FHMs. In total, 97 model parameters were fixed with values obtained from published literature or measured for this study (Table 1). The remaining 26 model parameters were calibrated using Markov Chain Monte Carlo simulation [44-47], which requires the definition of prior distributions for each parameter being calibrated.

Of the 26 calibrated model parameters, 17 were sensitive model parameters with little or no information available in the open literature (Table 2). Vague prior distributions were used for these 17 model parameters. For example, we could not find a published value for the dissociation constant of $E_{2}$ binding to ER in FHM brain specifically $\left(K_{\mathrm{d} \_ \text {E2ER, brn }}\right)$. Denny et al. [15] reported that the dissociation constant of $E_{2}$ binding in female FHM liver cytosol is $8.6 \mathrm{nmol} / \mathrm{L}$. As a result, we assigned a lognormal distribution with a geometric mean of 8.6 and a geometric standard deviation of three, which corresponds to a coefficient of variation equal to 1.5 . When no data were available in the open literature, we assigned a uniform or log-uniform prior distribution with a large range bounded by biological plausibility. For example, we know that the $\mathrm{EE}_{2}$ partition coefficient for blood to water is around 300 [20], and thus fixed the parameter value at 300 . However, there were no published data for the blood to water TB partition coefficient $\left(\lambda_{\mathrm{TB}}\right.$, bld $)$. Therefore, we assigned a vague prior distribution for $\lambda_{\mathrm{TB}}$, bld, which is a log-uniform distribution with a lower bound of one and an upper bound of 1000 .

The remaining nine parameters were error variances for plasma $E_{2}, T$, and VTG concentrations in unexposed, TB-exposed, and $\mathrm{EE}_{2}$-exposed FHMs. We assumed that the errors followed a lognormal distribution with geometric means equal to the model-predicted concentrations of plasma $\mathrm{E}_{2}, \mathrm{~T}$, and VTG, respectively. The variance was estimated by dividing the experimental data into three different groups: unexposed, TB-exposed, and $\mathrm{EE}_{2}$-exposed $\mathrm{FHM}$, respectively; and the error variances of the three reproductive endpoints for each group were estimated $[45,47]$. For each of the nine error variances, we assigned an Inverse Gamma prior distribution based upon a natural logarithm transformation of the measured plasma $E_{2}, T$ and VTG concentrations [20]. An Inverse Gamma prior distribution is the conjugate of a normal distribution [46], which simplifies the model computations.

To perform the Markov Chain Monte Carlo simulations, we used MCSim [48], a software package freely available online http://directory.fsf.org/math/mcsim. html. Four independent Markov chains with random seeds were run for 20,000 iterations. For each of the four chains, we saved the last 10,000 iterations, and extracted one set of model parameters out of every 10 . For each calibrated model parameter, convergence was evaluated using the 1,000 iterations from each chain and a potential scale reduction criterion (Rhat) [46]. Acceptable values of Rhat ranged from 1.0 to 1.2 ; this is essentially a ratio of the calibrated model parameter variance between the four Markov chains to the variance within a chain.

\section{Model Evaluation}

We evaluated the predictive ability of our model by simulating reproductive endpoints (i.e., plasma concentrations of $E_{2}$, $T$, or VTG) from independent studies. The 1,000 iterations obtained from each Markov chain were pooled, and the 4,000 sets of parameter values were treated as a pool of adult female FHMs. We randomly sampled $n$ (number of fish in a study) parameter sets to represent the $n$ fish used in the study, and simulated the reproductive endpoints measured for each fish. The detailed simulation procedures followed the methods described by Watanabe et al. [20].

After completing $n$ simulations for a study, we predicted each reproductive endpoint based upon our lognormal error model. As described in the Model Calibration section, error variances were estimated during model calibration. Using the model prediction and the estimated variance as two parameters, we randomly sampled from the lognormal distribution for each endpoint in each fish. The sampled values were compared with experimental measurements.

\section{Prediction of Unmeasured Reproductive Endpoints}

To observe EDC effects on unmeasured components of the HPG axis (e.g., ER, AR, and LH), and to observe the effects on reproductive endpoints by a mixture of TB and $\mathrm{EE}_{2}$, we did three extra simulations. We simulated liver ER concentration, brain AR concentration, and plasma $E_{2}, T, V T G$, and LH concentrations as a function of time in adult female FHMs exposed to $15 \mathrm{ng}$

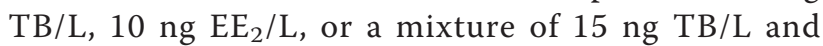

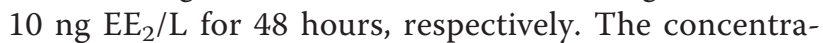
tions of $T B$ and $E E_{2}$ were chosen because they are environmentally relevant $[12,18,19]$. In all three simulations, we used the reported [38] median body weight, GSI, and HSI values in adult female FHMs as input parameters.

\section{Results and Discussion Model Calibration}

A good fit of the experimental data was obtained by running four Markov chains using the Markov Chain Monte Carlo simulations. For the 26 calibrated model parameters, the four Markov chains converged within 20,000 iterations. The model calibration speed is around 
Table 1 Model parameters treated as constants $(n=97)$

\begin{tabular}{|c|c|c|c|}
\hline Parameter description & Symbols & Value & Reference \\
\hline Body weight ${ }^{a}$ & BodyWt & $0.0016(\mathrm{~kg})$ & Watanabe et al. [38] \\
\hline Volumetric water flowing through gills & $\mathrm{FW}_{\mathrm{gil}}$ & 10.6× BodyWt ${ }^{0.75}(\mathrm{~L} / \mathrm{hr})$ & Nichols et al. [57] \\
\hline Cardiac output & $\mathrm{F}_{\mathrm{car}}$ & $2.06 \times$ BodyWt $^{0.75}(\mathrm{~L} / \mathrm{hr})$ & Nichols et al. [57] \\
\hline Percentage of brain to body weight (BSI) & $\mathrm{P}_{\mathrm{brn}}$ & 1.18 & Measured by D. Villeneuve \\
\hline Percentage of gonads to body weight $(G S I)^{b}$ & $P_{\text {gon }}$ & 11 & Watanabe et al. [38] \\
\hline Percentage of liver to body weight $(\mathrm{HSI})^{c}$ & $P_{\text {liv }}$ & 3.0 & Watanabe et al. [38] \\
\hline Percentage of gills to body weight & $P_{\text {gil }}$ & 1.67 & Nichols et al. [58] \\
\hline Percentage of venous blood to body weight & $P_{\text {ven }}$ & 2.59 & $\begin{array}{l}\text { Robinson et al. [59] } \\
\text { Nichols et al. [58] }\end{array}$ \\
\hline Percentage of "other" to body weight & $P_{\text {oth }}$ & $=100-P_{\text {brn }}-P_{\text {gon }}-P_{\text {liv }}-P_{\text {gill }}-P_{\text {ven }}$ & Watanabe et al. [20] \\
\hline \multirow{2}{*}{ Fraction of blood flow in brain to cardiac output } & $F_{b r n}$ & $0.036 \times P_{b r n}$ & \multirow{2}{*}{ Nichols et al. [58] } \\
\hline & $\overline{F_{c a r}}$ & $\overline{0.036 \times P_{b r n}+0.036 \times P_{\text {gon }}+0.024 \times P_{\text {liv }}+0.007 \times P_{\text {oth }}}$ & \\
\hline \multirow{2}{*}{ Fraction of blood flow in gonad to cardiac output } & $F_{\text {gon }}$ & $0.036 \times P_{\text {gon }}$ & \multirow{2}{*}{ Nichols et al. [58] } \\
\hline & $\overline{F_{c a r}}$ & $0.036 \times P_{\text {brn }}+0.036 \times P_{\text {gon }}+0.024 \times P_{\text {liv }}+0.007 \times P_{\text {oth }}$ & \\
\hline \multirow{2}{*}{ Fraction of blood flow in liver to cardiac output } & $F_{l i v}$ & $0.024 \times P_{l i v}$ & \multirow{2}{*}{ Nichols et al. [58] } \\
\hline & $\overline{F_{c a r}}$ & $\overline{0.036 \times P_{b r n}+0.036 \times P_{\text {gon }}+0.024 \times P_{\text {liv }}+0.007 \times P_{\text {oth }}}$ & \\
\hline \multirow{2}{*}{ Fraction of blood flow in "other" to cardiac output } & $F_{\text {oth }}$ & $0.007 \times P_{\text {oth }}$ & \multirow{2}{*}{ Nichols et al. [58] } \\
\hline & $\overline{F_{c a r}}$ & $\overline{0.036 \times P_{b r n}+0.036 \times P_{\text {gon }}+0.024 \times P_{l i v}+0.007 \times P_{\text {oth }}}$ & \\
\hline Fraction of plasma in venous blood & $F_{\text {plasma, ven }}$ & 0.45 & Measured by K. Kroll \\
\hline Total concentration of estrogen receptors in brain & $C_{E R, b r n}$ & 14.3 (nmol/L tissue) & $\begin{array}{c}\text { Plowchalk and Teaguarden } \\
{[60]}\end{array}$ \\
\hline Total concentration of estrogen receptors in gonad & $C_{E R, \text { gon }}$ & 29 (nmol/L tissue) & $\begin{array}{l}\text { Plowchalk and Teaguarden } \\
{[60]}\end{array}$ \\
\hline Total concentration of $\mathrm{LH}$ receptors in gonad & $C_{L R}$, gon & 2.0 (nmol/L tissue) & Miwa et al. [61] \\
\hline Total concentration of SBP in blood & $\mathrm{C}_{\mathrm{SBP} \text {, ven }}$ & $400(\mathrm{nmol} / \mathrm{L}$ blood $)$ & $\begin{array}{l}\text { Laidley and Thomas[37] } \\
\text { Teeguarden and Barton [36] }\end{array}$ \\
\hline Total concentration of AR in gonad & $C_{A R, \text { gon }}$ & 1.05 (nmol/L tissue) & Sperry and Thomas [62] \\
\hline Total concentration of AR in liver & $C_{A R, \text { liv }}$ & $=C_{A R, \text { gon }}$ & assumed \\
\hline Association rate of $E_{2}$ to estrogen receptor in brain & 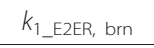 & 0.743 & Murphy et al. [63] \\
\hline Dissociation constant of $E_{2}$ to estrogen receptor in gonad & $K_{\mathrm{d} \_E 2 E R}$, gon & $=K_{d_{-} E 2 E R, ~ b r m}$ & assumed \\
\hline Association rate of $E_{2}$ to estrogen receptor in gonad & 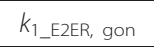 & $=k_{I_{-} \mathrm{E} 2 \mathrm{ER}, \mathrm{brn}}$ & assumed \\
\hline Dissociation constant of $E_{2}$ to estrogen receptor in liver & 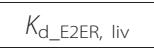 & $=K_{d_{-} \mathrm{E} 2 \mathrm{ER}, \mathrm{brn}}$ & assumed \\
\hline Association rate of $E_{2}$ to estrogen receptor in liver & $K_{1}$ E2ER, liv & $=k_{1} E 2 E R, b r n$ & assumed \\
\hline Dissociation constant of $\mathrm{EE}_{2}$ to estrogen receptor in brain & $K_{\text {d_EE2ER, brn }}$ & $=K_{d_{-} E 2 E R, \mathrm{brn}} / \mathrm{RBA}_{\mathrm{EE} 2 \_\mathrm{E} 2}$ & Denny et al. [15] \\
\hline Association rate of $\mathrm{EE}_{2}$ to estrogen receptor in brain & $k_{1}$ EE2ER, brn & $=k_{1} E 2 E R, \mathrm{brn}$ & assumed \\
\hline Dissociation constant of $\mathrm{EE}_{2}$ to estrogen receptor in gonad & $K_{\text {d_EE2ER, gon }}$ & 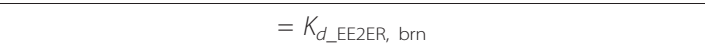 & assumed \\
\hline
\end{tabular}


Table 1 Model parameters treated as constants $(n=97)$ (Continued)

\begin{tabular}{|c|c|c|c|}
\hline Association rate of $\mathrm{EE}_{2}$ to estrogen receptor in gonad & 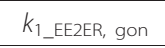 & 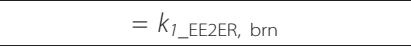 & assumed \\
\hline Dissociation constant of $\mathrm{EE}_{2}$ to estrogen receptor in liver & $K_{\text {d_EE2ER, liv }}$ & 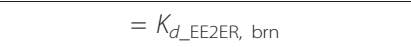 & assumed \\
\hline Association rate of $\mathrm{EE}_{2}$ to estrogen receptor in liver & 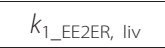 & $=k_{1}$ EE2ER, brn & assumed \\
\hline Dissociation constant of $\mathrm{T}$ to androgen receptor in brain & $K_{d_{-} T A R, b r n}$ & $3(\mathrm{nmol} / \mathrm{L})$ & Sperry and Thomas [62] \\
\hline Association rate of $\mathrm{T}$ to androgen receptor in brain & $k_{1}$ TAR, brn & $0.08(\mathrm{~L} / \mathrm{nmol} / \mathrm{hr})$ & Sperry and Thomas [62] \\
\hline Dissociation constant of T to androgen receptor in gonad & $K_{\text {d_tAR, gon }}$ & $=K_{d_{-} \mathrm{TAR}, \mathrm{brn}}$ & assumed \\
\hline Association rate of $\mathrm{T}$ to androgen receptor in gonad & $k_{1}$ TAR, gon & $=k_{1} \mathrm{TAR}_{\mathrm{B}} \mathrm{brn}$ & assumed \\
\hline Dissociation constant of $\mathrm{T}$ to androgen receptor in liver & $K_{\text {d_TAR, liv }}$ & $=K_{d_{-}} \mathrm{TAR}, \mathrm{brn}$ & assumed \\
\hline Association rate of $\mathrm{T}$ to androgen receptor in liver & $k_{1}$ TAR, liv & $=k_{1}{ }_{-} \mathrm{TAR}, \mathrm{brn}$ & assumed \\
\hline Dissociation constant of TB to androgen receptor in brain & $K_{\text {d_tBAR, brn }}$ & $=K_{d_{-} T A R, b r n} / R A_{T B_{-} T}$ & Wilson et al. [64] \\
\hline Association rate of TB to androgen receptor in brain & $k_{1 \_ \text {TBAR, brn }}$ & $=k_{1}$ TAR, brn & assumed \\
\hline Dissociation constant of TB to androgen receptor in gonad & $K_{\text {d_tBAR, gon }}$ & $=K_{d_{-} \mathrm{TBAR}, \mathrm{brn}}$ & assumed \\
\hline Association rate of TB to androgen receptor in gonad & k1_TBAR, gon & $=k_{1}$ TBAR, brn & assumed \\
\hline Dissociation constant of TB to androgen receptor in liver & $K_{\text {d_tBAR, liv }}$ & $=K_{d_{-} \mathrm{TBAR}, \mathrm{brn}}$ & assumed \\
\hline Association rate of TB to androgen receptor in liver & $k_{1}$ TBAR, liv & $=k_{1}{ }_{\text {TBAR, }} \mathrm{brn}$ & assumed \\
\hline Dissociation constant of $\mathrm{E}_{2}$ to SBP in blood & $K_{d_{d} E 2 S B P}$, ven & $3.13(\mathrm{nmol} / \mathrm{L})$ & Murphy et al. [63] \\
\hline Association rate of $E_{2}$ to SBP in blood & $k_{1 \_E 2 S B P}$, ven & $5.6687(\mathrm{~L} / \mathrm{nmol} / \mathrm{hr})$ & Murphy et al. [63] \\
\hline Dissociation constant of T to SBP in blood & $K_{\mathrm{d} \_T S B P}$, ven & $4.89(\mathrm{nmol} / \mathrm{L})$ & Murphy et al. [63] \\
\hline Association rate of T to SBP in blood & $K_{1}$ TSBP, ven & $5.6687(\mathrm{~L} / \mathrm{nmol} / \mathrm{hr})$ & Murphy et al. [63] \\
\hline Dissociation constant of $\mathrm{EE}_{2}$ to $\mathrm{SBP}$ in blood & $K_{d_{-} E E 2 S B P}$, ven & $0.58(\mathrm{nmol} / \mathrm{L})$ & $\begin{array}{l}\text { Miguel-Queralt and } \\
\text { Hammond [34] }\end{array}$ \\
\hline Association rate of $\mathrm{EE}_{2}$ to $\mathrm{SBP}$ in blood & $k_{1}$ EE2SBP, ven & $5.6687(\mathrm{~L} / \mathrm{nmol} / \mathrm{hr})$ & Murphy et al. [63] \\
\hline Dissociation constant of LH to LH receptor in gonad & $K_{\mathrm{d} \_L H L R, \text { gon }}$ & $2.9(\mathrm{nmol} / \mathrm{L})$ & Crim et al. [65] \\
\hline Association rate of LH to LH receptor in gonad & $k_{1} \_L H L R$, gon & $0.2(\mathrm{~L} / \mathrm{nmol} / \mathrm{hr})$ & Watanabe et al. [20] \\
\hline Scaling coefficient of $V_{\max }$ of $\mathrm{T}$ production in gonad $\left(=V_{\max } /\right.$ bodyweight $\left.{ }^{0.75}\right)$ & $\begin{array}{l}\text { sc_Vmax } \\
\text { gon }\end{array}$ & 1.1e+05 (nmol/hr/kg body weight) & $\begin{array}{l}\text { Kashiwagi et al. [66]; } \\
\text { Shikita and Hall [67] }\end{array}$ \\
\hline $\mathrm{K}_{0.5}$ of $\mathrm{T}$ production in gonad & $\mathrm{K}_{0.5 \mathrm{scc}, \text { gon }}$ & $190(\mathrm{nmol} / \mathrm{L})$ & Shikita and Hall [67] \\
\hline Inhibition constant of T production by bound ER & $\mathrm{K}_{\mathrm{T}}$ & 0.016 & Watanabe et al. [20] \\
\hline $\mathrm{Km}$ of $\mathrm{E}_{2}$ production in gonad & $\mathrm{Km}_{\text {aro, gon }}$ & 9.6 (nmol/L) & Zhao et al. [68] \\
\hline Concentration of microsomal protein in gonads & $\mathrm{D}_{\mathrm{mp}, \text { gon }}$ & $3100(\mathrm{mg} / \mathrm{L})$ & Measured by D. Villeneuve \\
\hline Ratio between the concentrations of microsoaml protein in gonads and brain & Rhomp & 0.174 & Measured by D. Villeneuve \\
\hline $\begin{array}{l}\text { Scaling coefficient of } V \max \text { of } \mathrm{E}_{2} \text { production in brain (= Vmax/mass of microsomal protein } \\
\text { in brain) }\end{array}$ & $\underset{\text { brn }}{\text { sc_Vmax }}$ & $=4.6 \times$ sc_Vmax $_{-}$aro, gon & Zhao et al. [68] \\
\hline $\mathrm{Km}$ of $\mathrm{E}_{2}$ production in brain & $\mathrm{Km}$ aro, brn & $9.6(\mathrm{nmol} / \mathrm{L})$ & Zhao et al. [68] \\
\hline Concentration of microsomal protein in brain & $\mathrm{D}_{\mathrm{mp}, \mathrm{bm}}$ & $=\mathrm{D}_{\mathrm{mp}, \mathrm{gon}} / \mathrm{Rho}_{\mathrm{mp}}$ & Measured by D. Villeneuve \\
\hline Ratio between concentrations of STAR and bound LR in gonads & RhO $_{S T A R, \text { gon }}$ & 1 & assumed \\
\hline
\end{tabular}


Table 1 Model parameters treated as constants $(n=97)$ (Continued)

\begin{tabular}{|c|c|c|c|}
\hline Rate constant for Vtg uptake into oocytes & $k_{\text {vtg, gon }}$ & 0.05 & assumed \\
\hline $\mathrm{K}_{0.5}$ of $\mathrm{Vtg}$ production in liver production & $\mathrm{K}_{0.5 \mathrm{Vtg} \text {, liv }}$ & $1.0(\mathrm{nmol} / \mathrm{L})$ & Watanabe et al. [20] \\
\hline $\begin{array}{l}\text { Elimination rate constant for ER } \\
\text { in the liver compartment }\end{array}$ & $k_{\text {e_ER, liv }}$ & $0.01(1 / \mathrm{hr})$ & Murphy et al. [63] \\
\hline $\begin{array}{l}\text { Elimination rate constant for AR } \\
\text { in the brain compartment }\end{array}$ & $k_{e \_A R, b r n}$ & $0.01(1 / h r)$ & Assumed \\
\hline $\begin{array}{l}\text { Elimination rate constant for LH } \\
\text { in the "other" compartment }\end{array}$ & Ke_LH, oth & $0.1(1 / h r)$ & Teeguarden and Barton [36] \\
\hline $\begin{array}{l}\text { Elimination rate constant for } E_{2} \\
\text { in the "other" compartment }\end{array}$ & $k_{\text {e_E2, oth }}$ & $0.1(1 / \mathrm{hr})$ & Teeguarden and Barton [36] \\
\hline $\begin{array}{l}\text { Elimination rate constant for } \mathrm{T} \\
\text { in the "other" compartment }\end{array}$ & $k_{e-T, \text { oth }}$ & $0.1(1 / h r)$ & Teeguarden and Barton [36] \\
\hline $\begin{array}{l}\text { Elimination rate constant for } \mathrm{EE}_{2} \\
\text { in the "other" compartment }\end{array}$ & $k_{\text {e_EE2, oth }}$ & $0.1(1 / \mathrm{hr})$ & Teeguarden and Barton [36] \\
\hline $\begin{array}{l}\text { Elimination rate constant for TB } \\
\text { in the "other" compartment }\end{array}$ & $k_{\mathrm{e}-\mathrm{TB}}$, oth & $0.1(1 / h r)$ & Teeguarden and Barton [36] \\
\hline $\begin{array}{l}\text { Elimination rate constant for Vtg } \\
\text { in the "other" compartment }\end{array}$ & 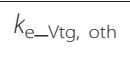 & $0.001(1 / h r)$ & Teeguarden and Barton [36] \\
\hline $\begin{array}{l}\text { Partition coefficient of LH } \\
\text { (brain to blood) }\end{array}$ & $\lambda_{\mathrm{LH}, \mathrm{brn}}$ & 1 & Teeguarden and Barton [36] \\
\hline $\begin{array}{l}\text { Partition coefficient of LH } \\
\text { (gonad to blood) }\end{array}$ & $\lambda_{\mathrm{LH}, \text { gon }}$ & 1 & Teeguarden and Barton [36] \\
\hline $\begin{array}{l}\text { Partition coefficient of LH } \\
\text { (liver to blood) }\end{array}$ & $\lambda_{\mathrm{LH}, \text { liv }}$ & 1 & Teeguarden and Barton [36] \\
\hline $\begin{array}{l}\text { Partition coefficient of LH } \\
\text { ("other" to blood) }\end{array}$ & $\lambda_{\mathrm{LH}, \text { oth }}$ & 1 & Teeguarden and Barton [36] \\
\hline $\begin{array}{l}\text { Partition coefficient of VTG } \\
\text { (brain to blood) }\end{array}$ & $\lambda_{V T G, \mathrm{brn}}$ & 1 & Teeguarden and Barton [36] \\
\hline $\begin{array}{l}\text { Partition coefficient of VTG } \\
\text { (gonad to blood) }\end{array}$ & $\lambda_{\mathrm{VTG}, \text { gon }}$ & 1 & Teeguarden and Barton [36] \\
\hline $\begin{array}{l}\text { Partition coefficient of VTG } \\
\text { (liver to blood) }\end{array}$ & $\lambda_{\mathrm{VTG}, \mathrm{liv}}$ & 1 & Teeguarden and Barton [36] \\
\hline $\begin{array}{l}\text { Partition coefficient of VTG } \\
\text { ("other" to blood) }\end{array}$ & $\lambda_{V T G, \text { oth }}$ & 1 & Teeguarden and Barton [36] \\
\hline $\begin{array}{l}\text { Partition coefficient of } \mathrm{EE}_{2} \\
\text { (blood to water) }\end{array}$ & $\lambda_{\mathrm{EE} 2, \mathrm{bld}}$ & 300 & Watanabe et al. [20] \\
\hline $\begin{array}{l}\text { Partition coefficient of } \mathrm{EE}_{2} \\
\text { (brain to blood) }\end{array}$ & $\lambda_{\mathrm{EE} 2, \mathrm{brn}}$ & 1 & Teeguarden and Barton [36] \\
\hline $\begin{array}{l}\text { Partition coefficient of } \mathrm{EE}_{2} \\
\text { (gonad to blood) }\end{array}$ & $\lambda_{\mathrm{EE} 2, \text { gon }}$ & 1 & Teeguarden and Barton [36] \\
\hline $\begin{array}{l}\text { Partition coefficient of } \mathrm{EE}_{2} \\
\quad \text { (liver to blood) }\end{array}$ & $\lambda_{\mathrm{EE} 2 \text {, liv }}$ & 3 & Watanabe et al. [20] \\
\hline
\end{tabular}




\begin{tabular}{|c|c|c|c|}
\hline $\begin{array}{l}\text { Partition coefficient of } \mathrm{EE}_{2} \\
\text { ("other" to blood) }\end{array}$ & $\lambda_{\mathrm{EE} 2, \text { oth }}$ & 1 & Teeguarden and Barton [36] \\
\hline $\begin{array}{l}\text { Partition coefficient of } E_{2} \\
\text { (blood to water) }\end{array}$ & $\lambda_{\mathrm{E} 2 \text {, bld }}$ & 300 & Watanabe et al. [20] \\
\hline $\begin{array}{l}\text { Partition coefficient of } E_{2} \\
\text { (brain to blood) }\end{array}$ & $\lambda_{\mathrm{E} 2, \mathrm{brn}}$ & 1 & Teeguarden and Barton [36] \\
\hline $\begin{array}{l}\text { Partition coefficient of } E_{2} \\
\text { (gonad to blood) }\end{array}$ & $\lambda_{\mathrm{E} 2, \mathrm{gon}}$ & 1 & $\begin{array}{l}\text { Plowchalk and Teeguarden } \\
{[60]}\end{array}$ \\
\hline $\begin{array}{l}\text { Partition coefficient of } E_{2} \\
\quad \text { (liver to blood) }\end{array}$ & $\lambda_{\mathrm{E} 2, \mathrm{liv}}$ & 3 & Watanabe et al. [20] \\
\hline $\begin{array}{l}\text { Partition coefficient of } E_{2} \\
\text { ("other" to blood) }\end{array}$ & $\lambda_{\mathrm{E} 2, \text { oth }}$ & 1 & $\begin{array}{l}\text { Plowchalk and Teeguarden } \\
{[60]}\end{array}$ \\
\hline $\begin{array}{l}\text { Partition coefficient of } \mathrm{T} \\
\text { (brain to blood) }\end{array}$ & $\lambda_{\mathrm{T}, \mathrm{brn}}$ & 1 & Barton and Andersen [69] \\
\hline $\begin{array}{l}\text { Partition coefficient of } \mathrm{T} \\
\text { (gonad to blood) }\end{array}$ & $\lambda_{\mathrm{T}, \text { gon }}$ & 1 & Barton and Andersen [69] \\
\hline $\begin{array}{l}\text { Partition coefficient of } \mathrm{T} \\
\text { (liver to blood) }\end{array}$ & $\lambda_{\mathrm{T}, \text { liv }}$ & 1 & Barton and Andersen [69] \\
\hline $\begin{array}{l}\text { Partition coefficient of T } \\
\text { ("other" to blood) }\end{array}$ & $\lambda_{\mathrm{T}, \mathrm{oth}}$ & 1 & Barton and Andersen [69] \\
\hline $\begin{array}{l}\text { Partition coefficient of TB } \\
\text { (brain to blood) }\end{array}$ & $\lambda_{T B, \mathrm{brn}}$ & 1 & Barton and Andersen [69] \\
\hline $\begin{array}{l}\text { Partition coefficient of TB } \\
\text { (gonad to blood) }\end{array}$ & $\lambda_{\mathrm{TB}, \text { gon }}$ & 1 & Barton and Andersen [69] \\
\hline $\begin{array}{l}\text { Partition coefficient of TB } \\
\text { (liver to blood) }\end{array}$ & $\lambda_{\mathrm{TB}, \text { liv }}$ & 1 & Barton and Andersen [69] \\
\hline $\begin{array}{l}\text { Partition coefficient of TB } \\
\text { ("other" to blood) }\end{array}$ & $\lambda_{\mathrm{TB}, \text { oth }}$ & 1 & Barton and Andersen [69] \\
\hline
\end{tabular}

${ }^{\mathrm{a}}, \mathrm{b}$, and ${ }^{\mathrm{c}}$ were assigned with measured values in each fish; the default values were used only when measured data were missing. 
Table 2 Summary statistics for prior and posterior distributions of calibrated model parameters $(n=26)$

\begin{tabular}{|c|c|c|c|c|c|c|}
\hline Parameter description & Symbols & $\begin{array}{c}\text { Prior } \\
\text { Distribution } \\
(\mathrm{P} 1, \mathrm{P} 2)^{\mathrm{a}}\end{array}$ & Reference & $\begin{array}{l}\text { Mean (Posterior } \\
\text { Distribution) }\end{array}$ & $\begin{array}{l}\text { Median (Posterior } \\
\text { Distribution) }\end{array}$ & $\begin{array}{l}\text { 95\% Confidence Interval } \\
\text { (Posterior Distribution) }\end{array}$ \\
\hline Partition coefficient of TB (blood to water) & $\lambda_{\mathrm{TB}, \mathrm{bld}}$ & $\begin{array}{l}\text { Loguniform } \\
(1,1.0 \mathrm{E}+3)\end{array}$ & Assumed & 7.47 & 7.47 & $(5.96,8.93)$ \\
\hline $\begin{array}{c}\text { Dissociation constant of } \mathrm{E}_{2} \text { binding to ER in } \\
\text { brain }(\mathrm{nmol} / \mathrm{L})\end{array}$ & $K_{\text {d_EEER, brn }}$ & $\begin{array}{l}\text { Lognormal } \\
\quad(8.6,3)\end{array}$ & Denny et al. [15] & 1.12 & 1.08 & $(0.71,1.87)$ \\
\hline Relative binding affinity of $E_{2}$ to $E_{2}$ for $E R$ binding & $\mathrm{RBA}_{\mathrm{EE} 2 \_\mathrm{E} 2}$ & $\begin{array}{l}\text { Lognormal } \\
(1.66,3)\end{array}$ & $\begin{array}{l}\text { Denny et al. [15] } \\
\text { Gale et al. [14] }\end{array}$ & 3.24 & 1.64 & $(0.030,16.79)$ \\
\hline Relative binding affinity of TB to T for AR binding & $\mathrm{RBA}_{\mathrm{TB}}{ }_{-} \mathrm{T}$ & $\begin{array}{l}\text { Lognormal } \\
(6.03,3)\end{array}$ & Wilson et al. [64] & 5.25 & 4.84 & $(2.29,10.76)$ \\
\hline $\begin{array}{l}\text { Inhibition factor for LH production by bound } \\
\text { AR (nmol/L) }\end{array}$ & $\rho_{\mathrm{d} \_L \mathrm{H}, \mathrm{brn}}$ & $\begin{array}{l}\text { LogUniform } \\
(0.01,1.0 \mathrm{E}+3)\end{array}$ & Assumed & 0.11 & 0.10 & $(0.042,0.21)$ \\
\hline $\begin{array}{l}\text { Induction factor for LH production by bound } \\
\qquad \mathrm{ER}(\mathrm{nmol} / \mathrm{L})\end{array}$ & $\rho_{\mathrm{u} \_\mathrm{LH}, \mathrm{brn}}$ & $\begin{array}{l}\text { LogUniform } \\
(0.01,1.0 \mathrm{E}+3)\end{array}$ & Assumed & 238 & 138 & $(4.23,864)$ \\
\hline Hill coefficient for T production & $n_{\mathrm{T}}$ & $\begin{array}{l}\text { Lognormal } \\
\quad(1.8,3)\end{array}$ & Murphy et al. [63] & 1.03 & 1.01 & $(0.93,1.19)$ \\
\hline Proportionality constant relating cholesterol to StAR & $\rho_{\text {Chol, gon }}$ & $\begin{array}{l}\text { Loguniform } \\
(1,5.0 \mathrm{E}+3)\end{array}$ & Artemenk et al. [70] & 2.37 & 1.83 & $(1.04,6.69)$ \\
\hline $\begin{array}{l}\text { Scaling coefficient of Vmax for } E_{2} \text { production in } \\
\text { gonad ( } \mathrm{nmol} / \mathrm{hr} / \mathrm{mg} \text { micro-protein) }\end{array}$ & sc_Vmaxaro, gon & $\begin{array}{l}\text { Loguniform } \\
(2.3 \mathrm{E}-5,0.23)\end{array}$ & Zhao et al. [71] & $1.56 \mathrm{E}-3$ & $1.53 \mathrm{E}-3$ & $(1.15 \mathrm{E}-3,2.12 \mathrm{E}-3)$ \\
\hline $\begin{array}{l}\text { Induction factor of } E_{2} \text { production by bound } \\
\qquad \mathrm{LH}(\mathrm{L} / \mathrm{nmol})\end{array}$ & $\rho_{\mathrm{E} 2 \_L H L R \text {, gon }}$ & $\begin{array}{l}\text { Loguniform } \\
(0.1,100)\end{array}$ & assumed & 79.84 & 82.79 & $(42.61,99.15)$ \\
\hline $\begin{array}{l}\text { Scaling coefficient of Vmax for Vtg production in } \\
\text { liver }\left(=\text { Vmax }_{\text {BoodyWeight }}{ }^{0.75}\right)\left(\mathrm{nmol} / \mathrm{hr} / \mathrm{kg}^{0.75}\right)\end{array}$ & sc_Vmax ${ }_{V t g}$, liv & $\begin{array}{l}\text { Loguniform } \\
(1,1.0 \mathrm{E}+4)\end{array}$ & Watanabe et al. [20] & 175 & 169 & $(121,271)$ \\
\hline Hill coefficient of Vtg production in liver & $n_{V T G}$ & $\begin{array}{l}\text { Uniform } \\
(1,10)\end{array}$ & Assumed & 2.88 & 2.87 & $(1.97,3.87)$ \\
\hline ER background production rate in liver (nmol/L/hr) & Pbger, liv & $\begin{array}{r}\text { Loguniform } \\
(5.0 \mathrm{E}-5,0.5)\end{array}$ & assumed & 0.12 & 0.12 & $(0.084,0.17)$ \\
\hline $\begin{array}{l}\text { Induction rate constant for ER production in } \\
\text { liver (1/hr) }\end{array}$ & $K_{E R}$, liv & $\begin{array}{l}\text { Lognormal } \\
(0.08,3)\end{array}$ & Watanabe et al. [20] & 0.027 & 0.025 & $(5.73 E-3,0.065)$ \\
\hline $\begin{array}{l}\text { AR background production rate in brain } \\
\text { (nmol/L/hr) }\end{array}$ & $\mathrm{Pbg}_{\mathrm{AR}, \mathrm{brn}}$ & $\begin{array}{l}\text { Loguniform } \\
(5.0 \mathrm{E}-5,0.5)\end{array}$ & assumed & 0.012 & 0.012 & $(9.1 \mathrm{E}-3,0.015)$ \\
\hline $\begin{array}{l}\text { Inhibition factor of AR production by free } \\
\text { androgens (nmol/L) }\end{array}$ & $K_{A R, b r n}$ & $\begin{array}{l}\text { Loguniform } \\
\qquad(5 \mathrm{E}-4,5)\end{array}$ & assumed & 3.95 & 4.08 & $(2.15,4.95)$ \\
\hline Magnitude of LH production (nmol/hr) & $\operatorname{Mag}_{\mathrm{LH}}$ & $\begin{array}{l}\text { Loguniform } \\
(2.7 \mathrm{E}-7,2.7 \mathrm{E}-3)\end{array}$ & Schulz et al. [72] & $8.86 \mathrm{E}-6$ & $8.75 \mathrm{E}-6$ & $(6.29 \mathrm{E}-6,1.20 \mathrm{E}-5)$ \\
\hline $\begin{array}{l}\text { Error variance of plasma } E_{2} \text { concentration in natural } \\
\text { log space for unexposed female FHMs }\end{array}$ & Var_Ln_CE2tot_pla_ngml & $\begin{array}{l}\text { Inverse Gamma } \\
\qquad(2,1.19)\end{array}$ & Bois et al. [73] & 0.52 & 0.51 & $(0.38,0.73)$ \\
\hline $\begin{array}{l}\text { Error variance of plasma T concentration in natural } \\
\text { log space for unexposed female FHMs }\end{array}$ & Var_Ln_CTtot_pla_ngml & $\begin{array}{l}\text { Inverse Gamma } \\
\qquad(2,0.53)\end{array}$ & Bois et al. [73] & 0.48 & 0.47 & $(0.34,0.69)$ \\
\hline
\end{tabular}


Table 2 Summary statistics for prior and posterior distributions of calibrated model parameters $(n=26)(C o n t i n u e d)$

\begin{tabular}{|c|c|c|c|c|c|c|}
\hline $\begin{array}{l}\text { Error variance of plasma VTG concentration in } \\
\text { natural log space for unexposed female FHMs }\end{array}$ & Var_Ln_CVTG_pla_mgml & $\begin{array}{l}\text { Inverse Gamma } \\
\qquad(2,5.31)\end{array}$ & Bois et al. [73] & 0.49 & 0.48 & $(0.35,0.68)$ \\
\hline $\begin{array}{l}\text { Error variance of plasma } E_{2} \text { concentration in natural } \\
\text { log space for TB-exposed female FHMs }\end{array}$ & Var_Ln_CE2tot_pla_ngml & $\begin{array}{l}\text { Inverse Gamma } \\
\qquad(2,1.19)\end{array}$ & Bois et al. [73] & 0.70 & 0.69 & $(0.48,1.03)$ \\
\hline $\begin{array}{l}\text { Error variance of plasma T concentration in natural } \\
\text { log space for TB-exposed female FHMs }\end{array}$ & Var_Ln_CTtot_pla_ngml & $\begin{array}{l}\text { Inverse Gamma } \\
\quad(2,0.53)\end{array}$ & Bois et al. [73] & 0.40 & 0.39 & $(0.27,0.60)$ \\
\hline $\begin{array}{l}\text { Error variance of plasma VTG concentration in } \\
\text { natural log space for TB-exposed female FHMs }\end{array}$ & Var_Ln_CVTG_pla_mgml & $\begin{array}{l}\text { Inverse Gamma } \\
\qquad(2,5.31)\end{array}$ & Bois et al. [73] & 5.86 & 5.72 & $(3.98,8.60)$ \\
\hline $\begin{array}{l}\text { Error variance of plasma } E_{2} \text { concentration in natural } \\
\text { log space for } E_{2} \text {-exposed female } F H M s\end{array}$ & Var_Ln_CE2tot_pla_ngml & $\begin{array}{l}\text { Inverse Gamma } \\
\qquad(2,1.19)\end{array}$ & Bois et al. [73] & 1.43 & 0.81 & $(0.22,6.31)$ \\
\hline $\begin{array}{l}\text { Error variance of plasma T concentration in natural } \\
\text { log space for } \mathrm{EE}_{2} \text {-exposed female } \mathrm{FHMs}\end{array}$ & Var_Ln_CTtot_pla_ngml & $\begin{array}{l}\text { Inverse Gamma } \\
\qquad(2,0.53)\end{array}$ & Bois et al. [73] & 0.59 & 0.34 & $(0.10,2.76)$ \\
\hline $\begin{array}{l}\text { Error variance of plasma VTG concentration in } \\
\text { natural log space for } \mathrm{EE}_{2} \text {-exposed female FHMs }\end{array}$ & Var_Ln_CVTG_pla_mgml & $\begin{array}{l}\text { Inverse Gamma } \\
\quad(2,5.31)\end{array}$ & Bois et al. [73] & 0.73 & 0.71 & $(0.51,1.03)$ \\
\hline
\end{tabular}

${ }^{a}$ Definition of $\mathrm{P} 1$ and $\mathrm{P} 2$ of prior distributions. Loguniform: $\mathrm{P} 1=$ minimum of the sampling range in natural space; $\mathrm{P} 2$ = maximum of the sampling range in natural space. Lognormal: $\mathrm{P} 1=$ geometric mean

(exponential of the mean in log-space); P2 = geometric standard deviation (exponential of the standard deviation in log-space, strictly superior to 1 ). Uniform: P1 = minimum of the sampling range in natural space;

$\mathrm{P} 2=$ maximum of the sampling range in natural space. Inverse gamma: $\mathrm{P} 1=$ shape; $\mathrm{P} 2=$ scale (both of the parameters are strictly positive). 
12 hours per 100 iterations. The Rhat values of the 26 parameters were all less than 1.2, indicating acceptable convergence. Figure 2 plots the trajectories of the four Markov chains for the relative binding affinity of TB to $\mathrm{T}\left(\mathrm{RBA}_{\mathrm{TB} \mathrm{T}_{\mathrm{T}}}\right)$, which is one of the 26 calibrated model parameters. The four chains for this parameter mixed well and converged within 20,000 iterations.

Table 2 includes the summary statistics of posterior distributions for the 26 calibrated parameters. The posterior distribution summary statistics are based on the 4,000 iterations, 1,000 iterations from each of the four chains. In brief, our model improved estimates of 23 model parameters. Of the 26 parameters, 21 had $95 \%$ confidence intervals (CIs) narrower than those of their prior distributions; three parameters (i.e., RBA $\mathrm{EE2}_{\mathrm{E} 2}$, error variances of $E_{2}$ and $T$ for $E_{2}$-exposed $F H M s$ ) had 95\% CIs similar to their prior distribution CIs; and two parameters (i.e., error variances of VTG in unexposed and $\mathrm{EE}_{2}$-exposed FHMs) had 95\% CIs slightly different from their prior distribution CIs. For the error variance of VTG in unexposed FHMs, the upper 95\% confidence limit of the posterior distribution was $72 \%$ of the $2.5^{\text {th }}$ percentile of its prior distribution. For the error variances of VTG in $\mathrm{EE}_{2}$-exposed FHMs, the 95\% CIs of the prior and posterior distributions overlapped with each other. But the upper 95\% confidence limit of the posterior distribution was only $5 \%$ of the $97.5^{\text {th }}$ percentile of its prior distribution. These large differences occurred mainly because the assigned prior distributions for the error variances were based upon experimental data variances, which do not represent the errors exactly, but were good starting points for the model calibration.

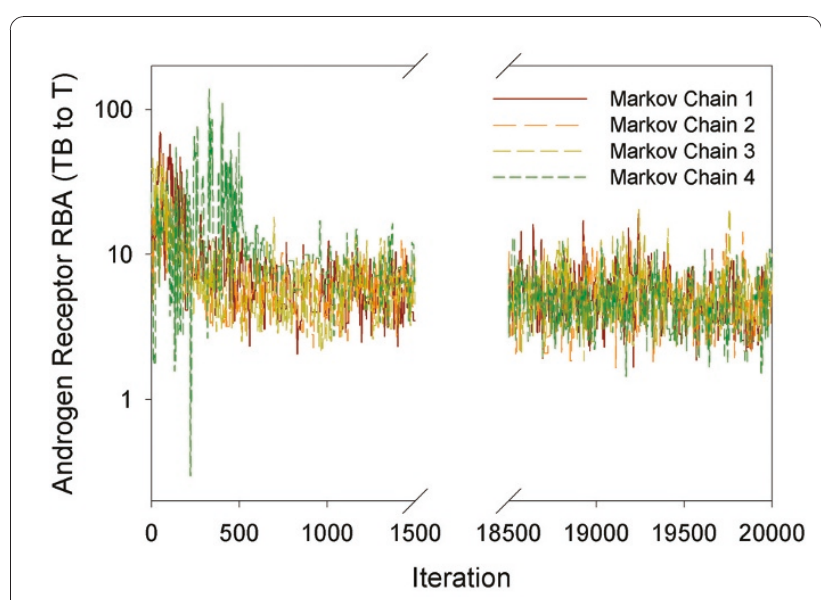

Figure 2 Four Markov chains. Androgen receptor relative binding affinity (RBA) for $T B$ relative to $T\left(R B A_{T B_{-}} T\right)$. This is one of the 26 calibrated model parameters illustrating well-mixed Markov chain trajectories.
It is important to note that the posterior distributions listed in Table 2 are conditional upon fixed model parameters (Table 1), prior distributions of calibrated parameters (Table 2), and the data sets used in calibration. Any change in these components may lead to different posterior distributions of the calibrated parameters. In this study, we carefully searched the literature to assign our model parameters with meaningful and physiologically based values or prior distributions. As additional data become available, our model could be re-calibrated to better define parameter posterior distributions.

\section{Model Evaluation}

In this study, our model was used to simulate experiments ranging in length from 48 hrs to 21 days. The model is capable of simulating longer periods of time, but it does not include a seasonal component. That is, the FHMs simulated in our study were held under laboratory conditions optimal for reproduction and spawn year round. The model could be modified to account for the effect of seasons upon reproduction in order to simulate conditions experienced by wild fish.

\section{Predictions for Plasma $E_{2}, T$, and VTG Concentrations in Unexposed FHMs}

With the calibrated model parameters, we simulated plasma concentrations of $\mathrm{E}_{2}, \mathrm{~T}$, and VTG in 95 unexposed adult female FHMs [38]. Figure 3 shows a comparison of model predictions and experimental data. For all three endpoints, the mean and median model predictions were within 80 to $150 \%$ of the measured means and medians, respectively. Model-predicted 95\% CIs encompassed the mean and median measurements, and model-predicted means and medians were within the $95 \%$ CIs of the measured data. Thus, in unexposed adult female FHMs, our model successfully predicted all three endpoints (Figure 3 ). This is an improvement compared to the model for male FHMs [20], which predicted the medians of the measured data, but under-predicted the variances for all three endpoints. Including information from the lognormal error model enabled better predictions of both medians and variances of the measured data.

\section{Predictions for plasma E2 and VTG concentrations in TB- exposed FHMs}

Figure 4 compares the measured and model-predicted plasma VTG (Figure 4A) and $\mathrm{E}_{2}$ (Figure 4B) concentrations in female FHMs exposed to 0, 0.05, 0.5, and $5 \mu \mathrm{g}$ TB/L for 48 hours [39]. Our model predictions followed the general trend of the measured data, and the model prediction range overlapped with the measured data range for both endpoints at each TB concentration. For plasma VTG concentrations, the median model predictions were within $96 \%$ to $579 \%$ of the 


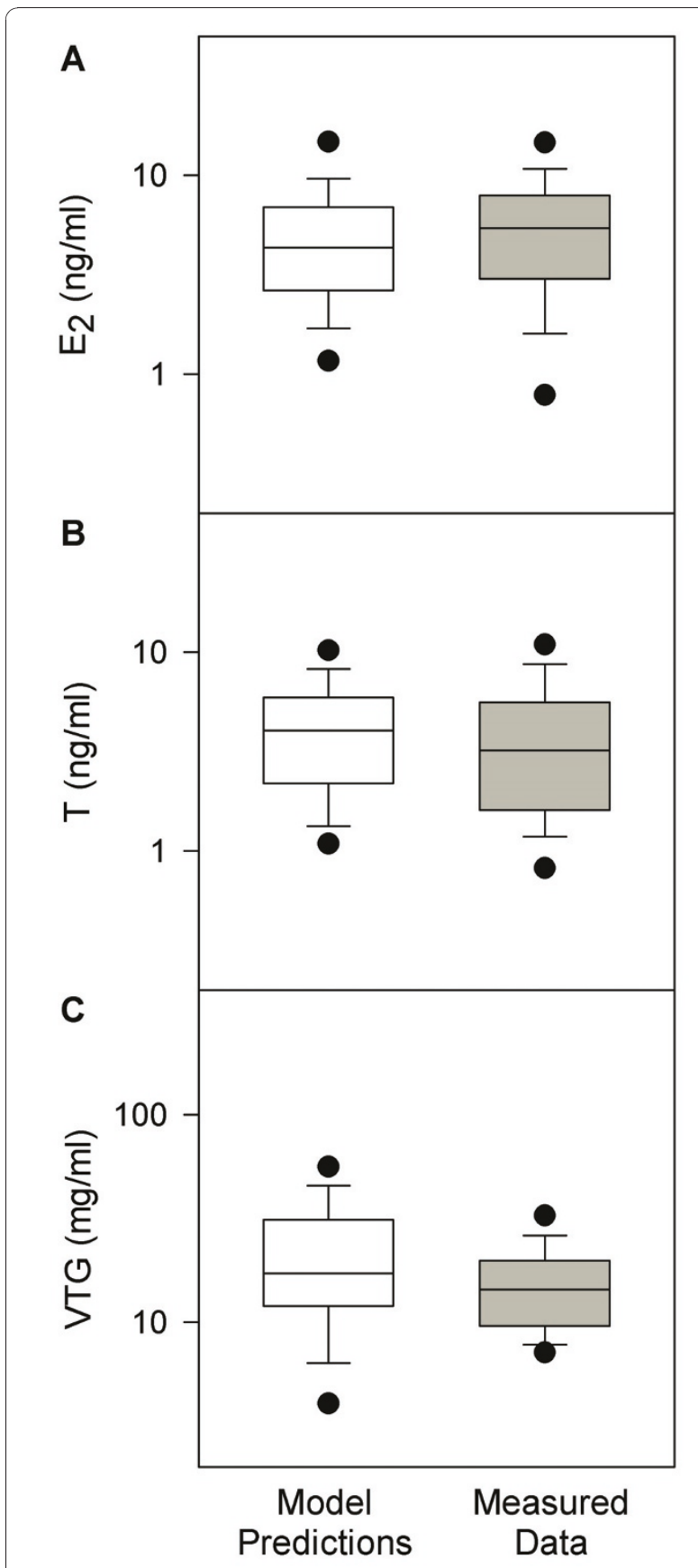

Figure 3 Comparison of model predictions with measured data in unexposed female FHMs. $n=95$. White boxes represent model predictions, and grey boxes represent measured data [38]. The solid line within the box marks the median; the boundary of the box farthest from zero indicates the $75^{\text {th }}$ percentile; the boundary of the box closest to zero indicates the $25^{\text {th }}$ percentile; the whisker (error bar) farthest from zero marks the $90^{\text {th }}$ percentile; whisker (error bar) closest to zero marks the $10^{\text {th }}$ percentile; the circle farthest from zero marks the $95^{\text {th }}$ percentile; and the circle closest to zero marks the $5^{\text {th }}$ percentile. median measurements. The $579 \%$ difference seems high, and as a result, we looked into details particularly for this model prediction. We found that this prediction happened when TB concentration equal to $0.5 \mu \mathrm{g} /$ L. At this TB concentration, we collected plasma VTG concentrations in each of 4 adult female FHMs, which were $4.61,26.21,1.99$, and $0.06 \mathrm{mg} / \mathrm{ml}$. The last measurement $(0.06 \mathrm{mg} \mathrm{VTG} / \mathrm{ml})$ is more than 30 -fold lower than the second lowest measurement $(1.99 \mathrm{mg}$ VTG/ml). As a result, this data point is an outlier, and our model did not capture it. If we exclude this data point, our model predictions $(17.63,20.54$, and 5.07 $\mathrm{mg} / \mathrm{ml}$ ) would match the experimental data well. For plasma $E_{2}$ concentrations, the median model predictions were within 44 to $113 \%$ of the median measurements. Kolmogorov-Smirnov tests $(\alpha=0.05)$ showed that the model predictions were not significantly different from the measured data for both plasma VTG and $\mathrm{E}_{2}$ concentrations.

To further evaluate the model's predictive ability for TB-exposed FHMs, we simulated plasma $E_{2}$ and VTG concentrations in FHMs exposed to 0, 0.05, and $0.5 \mu \mathrm{g}$ $\mathrm{TB} / \mathrm{L}$ for 8 days followed by an 8-day depuration [40]. For plasma $\mathrm{E}_{2}$ concentrations (Figure $5 \mathrm{~A}, \mathrm{~B}$, and $5 \mathrm{C}$ ), the 95\% CIs of model predictions encompassed the medians of the measured data for 16 out of 24 experimental conditions (eight sampling times and three different TB concentrations). Generally, our model predicted the plasma $E_{2}$ concentrations better during the TB exposure phase than during the depuration phase. This is not surprising since we only calibrated the model with experimental data from a TB exposure [7]. In addition, it is interesting to see that the measured plasma $\mathrm{E}_{2}$ concentrations declined from the $\mathrm{t}=\mathrm{P} 48$ to P192 hours for both control FHMs and FHMs exposed to different concentrations of TB. However, the model predictions showed a different trend; that is, for control FHMs, the predicted plasma $E_{2}$ concentrations remained relatively stable throughout the experimental period (Figure 5A); for TB-exposed FHMs, after the exposure, the plasma $\mathrm{E}_{2}$ concentrations increased and recovered to concentrations seen in unexposed FHMs. Since the measured plasma $\mathrm{E}_{2}$ concentrations decreased in both control FHMs and FHMs exposed to TB, we suspect that there might be some experimental factors that we have not accounted for in the model during the depuration phase.

Figure 5D, E, and 5F compare model-predicted plasma VTG concentrations with the measured data. The median model predictions were within 0.2 to 3.6 fold of the measured median, and the $95 \%$ CIs of model predictions encompassed all the measured medians at each sampling time. These results show that the model worked well for 

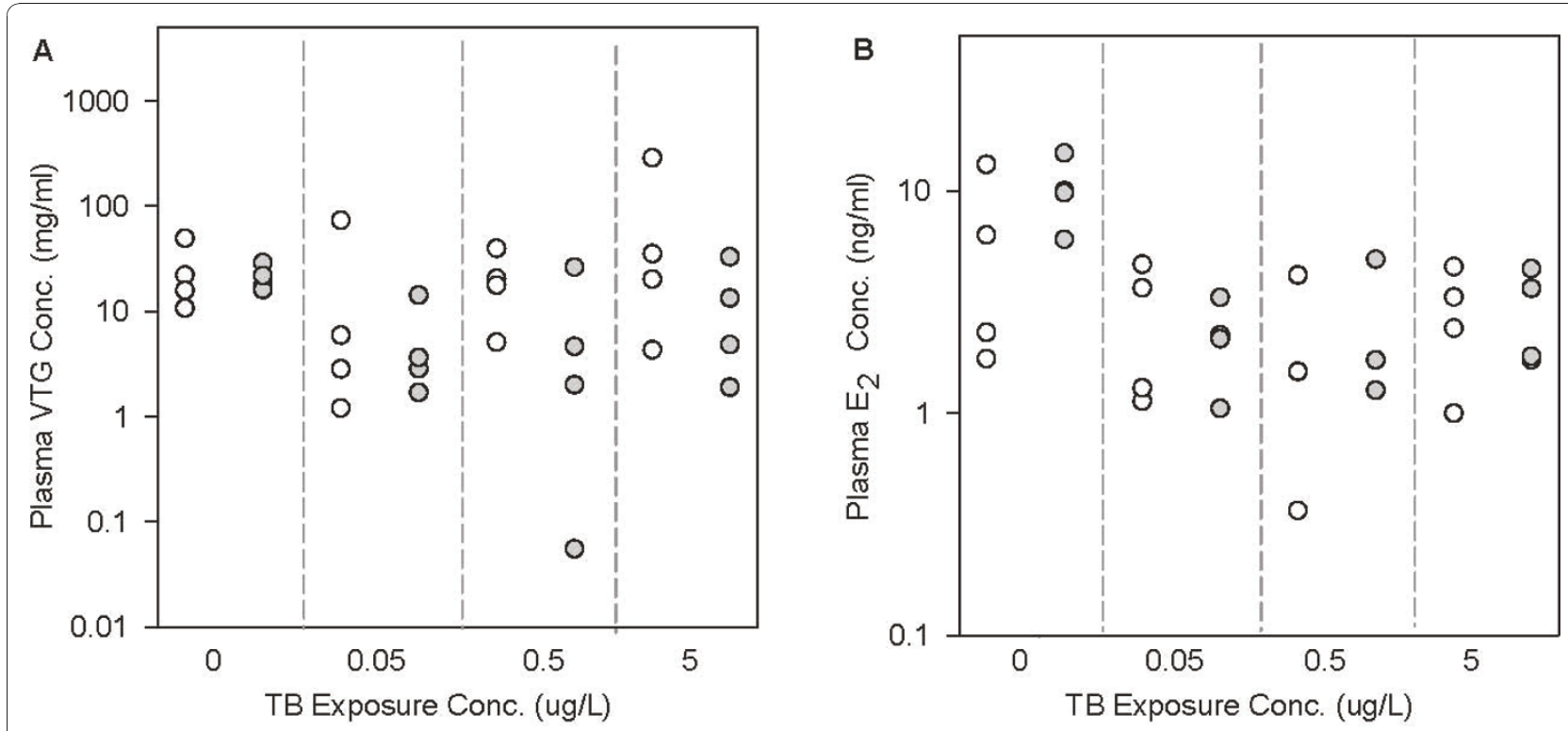

Figure 4 Comparison of model predictions with measured data in female FHMs exposed to TB for $\mathbf{4 8}$ hours. $n=32$. White circles represent model predictions, and grey circles represent measured data [39]. Each circle represents one measurement in one fish. (A) plasma VTG concentrations, and (B) plasma $E_{2}$ concentrations. The $x$-axis represents $T B$ concentrations in $\mu g / L$. Note: for panel B, at $0.5 \mu g$ TB/L, there are only 3 measured data points.

predicting the plasma $\mathrm{E}_{2}$ and $\mathrm{VTG}$ concentrations in female FHMs exposed to 0, 0.05, and $0.5 \mu \mathrm{g}$ TB/L for eight days.

After being calibrated with the experimental data from Ankley et al. [7], our model accurately predicted the plasma $E_{2}, T$, and VTG concentrations in adult female FHMs exposed to TB. This was achieved by simulating AR-related ligand-receptor binding processes, and by assuming two gene regulation mechanisms: i) down regulation of AR production by free androgens; and ii) down regulation of $\mathrm{LH}$ production by bound AR. It is noteworthy that the model was able to accurately fit not only the calibration data (see Additional file 2), but also the VTG and $E_{2}$ data from independent studies by GarciaReyero et al. [39] and Ekman et al. [40]. These results indicate that our AR-based modelling framework is plausible, and could be used in studies focused on regulatory aspects of the AR on HPG function. In a recent study, Shoemaker et al. [49] developed a computational model to simulate more detailed biochemical reactions in the FHM steroidogenic pathway. However, their model did not incorporate any AR-related signalling pathways. As AR plays an essential role for androgen responses and subsequent regulation of steroidogenesis, our model advances the work of Shoemaker et al. [49] by simulating AR-related signalling pathways.

The calibration and evaluation results showed that the model was able to predict the three reproductive endpoints from different studies with different experimental conditions. Although the data sets used to calibrate and validate the model were from studies with different experimental designs and analytic methods, the model accounted for the differences and predicted the endpoints well. For example, the calibration data were measured in FHMs exposed to TB for 21 days with a flowthrough water exposure design, and the plasma VTG concentrations were measured by a polyclonal FHMbased ELISA [7]. In contrast, one validation data set was from FHMs exposed to TB for 48 hours with a static water exposure design, and plasma VTG concentrations measured using a monoclonal carp-based ELISA [39], while the other validation data set was from FHMs exposed to TB for 8 days followed by an 8 day depuration in a flow-through system, with plasma VTG concentrations measured using the polyclonal FHM-based ELISA. With the parameter set calibrated with the data from one study, our model predicted plasma $\mathrm{E}_{2}$ and VTG concentrations comparable to the measurements from the other two studies. This indicates that the model not only fit the data empirically, but also captured major features of the HPG axis in female FHMs exposed to TB. In addition, the two model evaluations also supported the point by Watanabe et al. [20] that the VTG measurements by a polyclonal FHM-based ELISA and by a monoclonal carpbased ELISA are consistent.

\section{Predictions for plasma VTG concentrations in $\mathrm{EE}_{2}$-exposed FHMs}

Figure 6 compares model-predicted and measured plasma VTG concentrations in female FHMs exposed to 

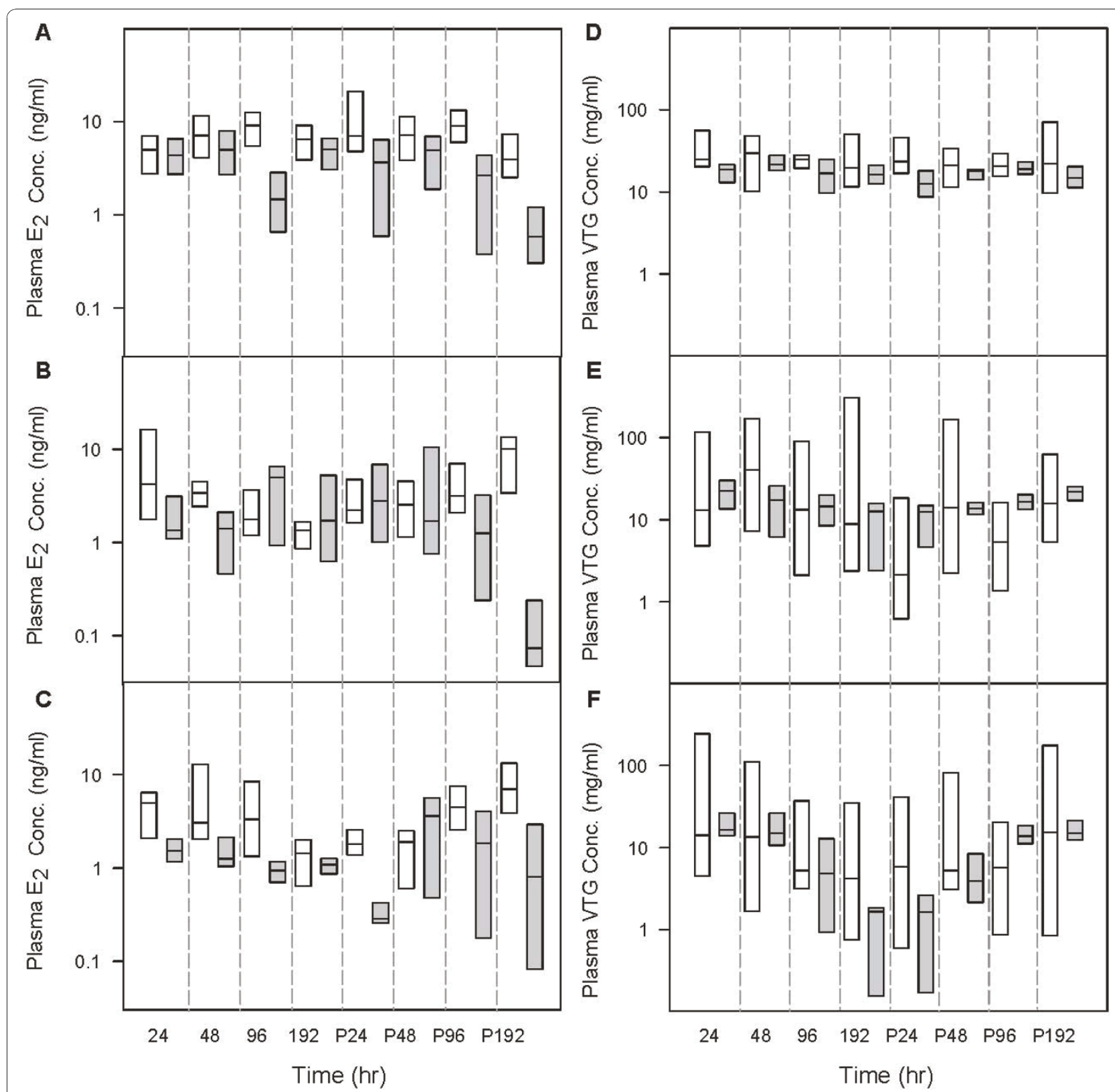

Figure 5 Comparison of model predictions with measured data in female FHMs exposed to TB for eight days followed by an eightday depuration. $n=8$ at each sampling time. White boxes represent model predictions, and grey boxes represent measured data [40]. The solid line within the box marks the median; the boundary of the box farthest from zero indicates the $75^{\text {th }}$ percentile; the boundary of the box closest to zero indicates the $25^{\text {th }}$ percentile. Because of the small data size $(n=8)$, the plots only show the $50 \%$ confidence intervals. (A) plasma $E_{2}$ concentrations in control FHMs, (B) plasma $E_{2}$ concentrations in FHMs exposed to $0.05 \mu \mathrm{g} T B / L$, (C) plasma $E_{2}$ concentrations in FHMs exposed to $0.5 \mu \mathrm{g} T \mathrm{~T} / \mathrm{L}$, (D) plasma VTG concentrations in control FHMs, (E) plasma VTG concentrations in FHMs exposed to $0.05 \mu \mathrm{g} T \mathrm{~TB} / \mathrm{L}$, (F) plasma VTG concentrations in FHMs exposed to $0.5 \mu \mathrm{g}$ TB/L. The x-axis represents time in hours. P24, P48, P96, and P192 represent 24, 48, 96, and 192 hours post-exposure, respectively.

three different concentrations of $\mathrm{EE}_{2}$ for 21 days [42]. For the $0.5,1.5$ and $4.5 \mathrm{ng} / \mathrm{L}$ exposures, respectively, the $90 \%, 80 \%$, and $50 \%$ CIs of model-predicted VTG concentrations encompassed the medians of the measured data. This trend suggests that the model predicts the endpoint better when the $\mathrm{EE}_{2}$ exposure concentration is high and closer to the exposure concentrations used to calibrate the model (i.e., 10 and $100 \mathrm{ng} \mathrm{EE}_{2} / \mathrm{L}$ ). For FHMs exposed to $4.5 \mathrm{ng} \mathrm{EE}_{2} / \mathrm{L}$, the median of our model predictions was around 2 times higher than the measured data, and all measured data were within the 95\% CIs of the model predictions. Considering that 


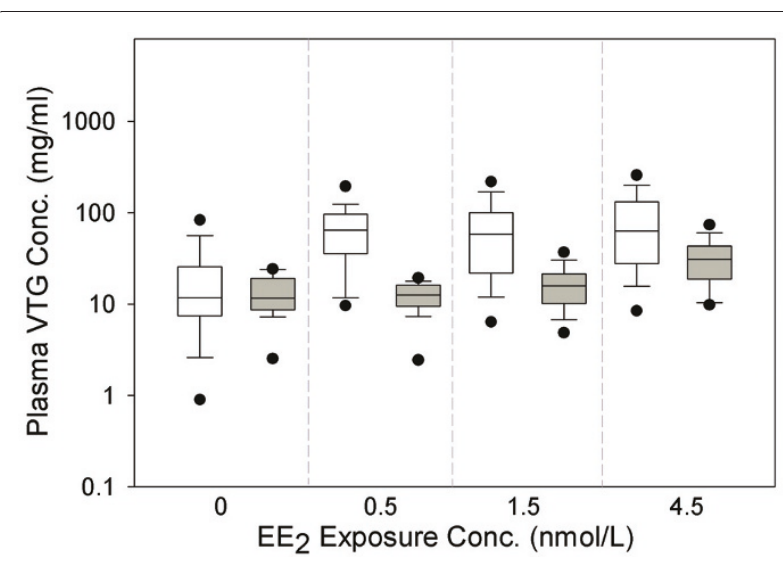

Figure 6 Comparison of model predictions with measured data in female FHMs exposed to $\mathrm{EE}_{2} \cdot n=28$ at each sampling time. White boxes represent model predictions, and grey boxes represent measured data [42]. The $\mathrm{x}$-axis represents $\mathrm{EE}_{2}$ concentrations in $\mathrm{ng} /$ $\mathrm{L}$. The solid line within the box marks the median; the boundary of the box farthest from zero indicates the $75^{\text {th }}$ percentile; the boundary of the box closest to zero indicates the $25^{\text {th }}$ percentile; the whisker (error bar) farthest from zero marks the $90^{\text {th }}$ percentile; whisker (error bar) closest to zero marks the $10^{\text {th }}$ percentile; the circle farthest from zero marks the $95^{\text {th }}$ percentile; and the circle closest to zero marks the $5^{\text {th }}$ percentile.

exposure concentrations less than $10 \mathrm{ng} \mathrm{EE}_{2} / \mathrm{L}$ and exposure durations longer than 8 days are an extrapolation of the model, model predictions of plasma VTG concentrations for the 21-day $4.5 \mathrm{ng} \mathrm{EE}_{2} / \mathrm{L}$ exposure were a surprisingly good fit. The low exposure concentration, longer time frame exposure is more environmentally relevant because $\mathrm{EE}_{2}$ concentrations range from 0.5 to $15 \mathrm{ng} \mathrm{EE}_{2} / \mathrm{L}$ in the aquatic environment [50-53], and aquatic animals may be exposed to the chemical throughout their lifetime.

Additionally, we simulated plasma VTG concentrations in FHMs exposed to $1.5 \mathrm{ng} \mathrm{EE}_{2} / \mathrm{L}$ for 21 days as reported by Brian et al. [43]. In total, four control FHMs and four FHMs exposed to $\mathrm{EE}_{2}$ were simulated. Brian et al. measured the VTG concentrations with a polyclonal carp VTG ELISA, which uses polyclonal antibodies prepared from carp VTG. In contrast, VTG data used to calibrate the model were measured with a homologous FHM VTG ELISA, which uses polyclonal antibodies prepared from FHM VTG. Direct comparison of the two methods have shown that measurements of FHM plasma VTG concentrations can differ by several orders of magnitude [54]. As a result, instead of comparing the model predictions with the measured data directly, we compared the relative changes of plasma VTG concentrations. The results showed that the range of model-predicted relative change was 0.44 to 4.93 , while the range of the measured data relative change was 0.78 to 0.82 , all within the range of model predictions.

\section{Predictions for reproductive endpoints in a mixture of TB} and $\mathrm{EE}_{2}$

In the next phase of our analysis, we predicted liver ER concentration, brain AR concentration, and plasma $E_{2}$, T, VTG, and luteinizing hormone (LH) concentrations

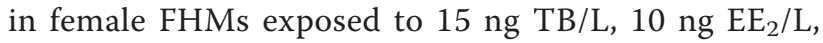
and a mixture of $15 \mathrm{ng} \mathrm{TB} / \mathrm{L}$ and $10 \mathrm{ng} \mathrm{EE}_{2} / \mathrm{L}$ for 48 hours, respectively. For all endpoints, there was a change after the chemical exposure began followed by a recovery to baseline values after the exposure ended. In panels $\mathrm{A}, \mathrm{B}$, and $\mathrm{C}$, after exposure to $\mathrm{TB}$, the plasma $E_{2}, T$, and VTG concentrations followed a trend consistent with the data used in the model calibration and evaluation. After exposure to $\mathrm{EE}_{2}$, plasma $\mathrm{E}_{2}$ and $\mathrm{T}$ concentrations decreased more dramatically than that produced by TB exposure. We did not find any reports of plasma $E_{2}$ or $T$ concentrations in female FHMs exposed to $\mathrm{EE}_{2}$. However, in female zebrafish, it was observed that both plasma $E_{2}$ and $T$ concentrations decreased after exposure to $15 \mathrm{ng} \mathrm{EE}_{2} / \mathrm{L}$ for 48 hours [55], which agrees with our model predictions. In addition, plasma VTG concentrations increased after exposure to $E_{2}$, consistent with the data used to calibrate and evaluate our model. Interestingly, after exposure to a mixture of $\mathrm{TB}$ and $\mathrm{EE}_{2}$, our model predicted that the plasma $E_{2}$ and $T$ concentrations decreased in an additive manner. In contrast, the plasma VTG concentration increased and followed the trend of an $\mathrm{EE}_{2}$ exposure.

In panels D, E, and $\mathrm{F}$ of Figure 7, we plotted liver $\mathrm{ER}$, brain AR, and plasma LH concentrations, respectively, as a function of time under the three different exposure conditions. Liver ER concentrations were predicted to decrease slightly after exposure to TB, and increase dramatically after exposure to $E_{2}$ and in response to the mixture. Predicted liver ER concentrations after $E_{2}$ exposure are consistent with the gene expression data in female FHMs exposed to $10 \mathrm{ng}$ $\mathrm{EE}_{2} / \mathrm{L}$ [56]. Brain AR concentrations were predicted to increase after exposure to $\mathrm{TB}$ and the mixture, and decrease slightly after exposure to $\mathrm{EE}_{2}$. Plasma $\mathrm{LH}$ concentrations were predicted to decrease after exposure to TB and the mixture, and increase slightly after exposure to $\mathrm{EE}_{2}$ (consistent with observations in teleosts exposed to $\mathrm{EE}_{2}$ [25]). To date, we do not have published data to evaluate model-predicted effects for a mixture of $\mathrm{TB}$ and $\mathrm{EE}_{2}$. In addition, three of the predicted endpoints (liver ER, brain AR, and plasma LH concentrations) have not been measured in FHM at a protein level because of experimental limitations. However, the predictions can be used to generate hypotheses and help explore possible mechanisms and pathways, which might be tested in the future. 

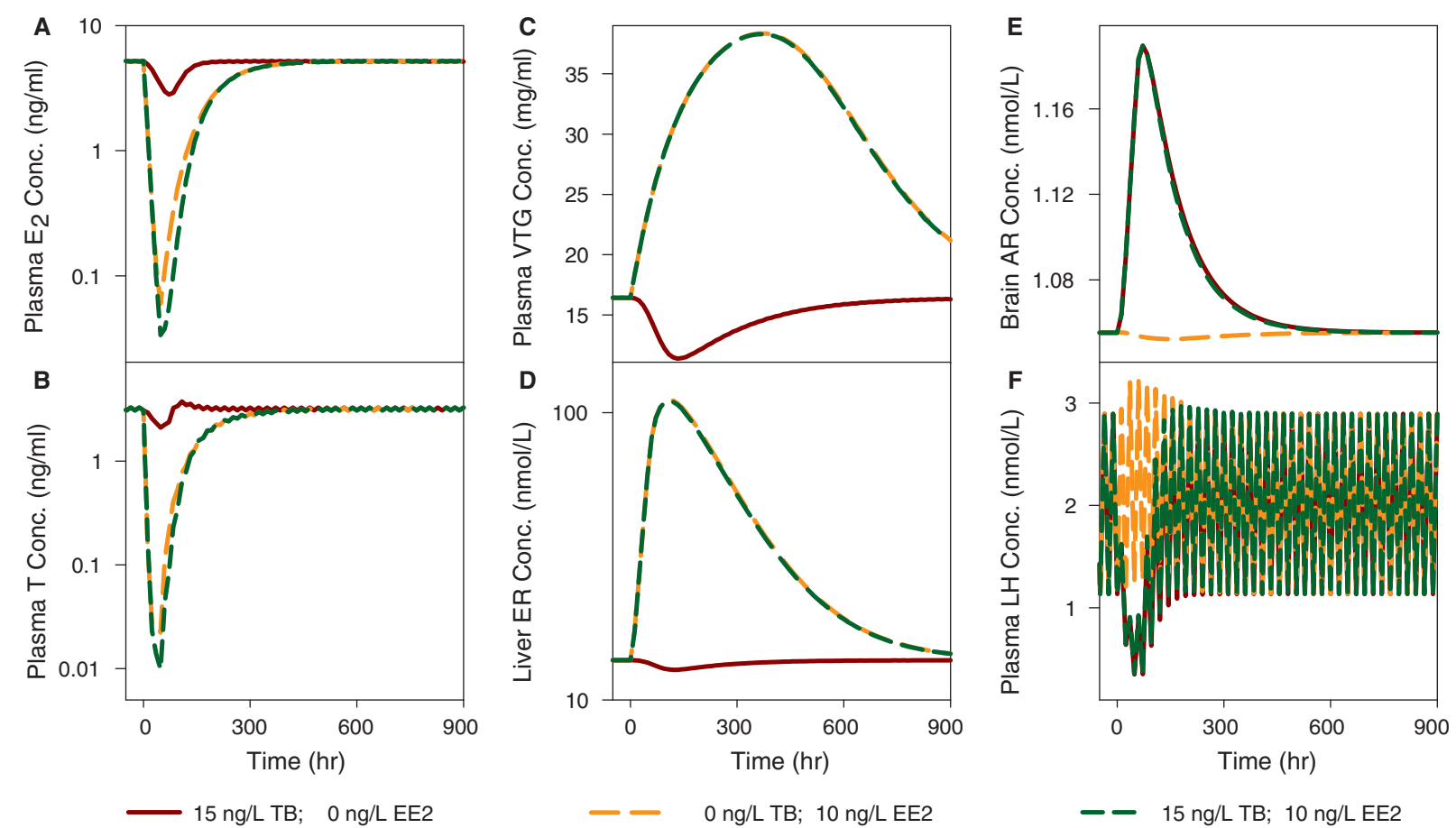

Figure 7 Model predictions for unmeasured reproductive endpoints in female FHMs. The predictions are for female FHMs exposed to 15 $\mathrm{ng} / \mathrm{L} \mathrm{TB}, 10 \mathrm{ng} / \mathrm{L} \mathrm{EE}_{2}$, or a mixture of $15 \mathrm{ng} / \mathrm{L} \mathrm{TB}$ and $10 \mathrm{ng} / \mathrm{L} \mathrm{EE}_{2}$ for 48 hours, respectively: (A) plasma $\mathrm{E}_{2}$ concentration, (B) plasma $\mathrm{T}$ concentration, (C) plasma VTG concentration, (D) liver ER concentration, (E) brain AR concentration, and (F) plasma LH concentration.

\section{Conclusions}

The model represents the HPG axis in adult female FHM robustly, and predicts plasma $\mathrm{E}_{2}$, T and VTG concentrations in female FHMs exposed to $\mathrm{TB}, \mathrm{EE}_{2}$, or a mixture of $\mathrm{TB}$ and $\mathrm{EE}_{2}$. This model links environmental estrogen and androgen exposure to changes in apical reproductive endpoints, and serves as a foundation that can be extended to simulate oocyte growth dynamics and other aspects of reproduction. In this study, the model predicted reproductive endpoints from independent studies well. For more than $85 \%$ of the simulation results, the $95 \%$ CIs of model predictions encompassed the median of the experimental data. To further evaluate the model's predictive ability, more experimental data are needed, especially for the endpoints in FHMs exposed to a mixture of $\mathrm{TB}$ and $\mathrm{EE}_{2}$.

Important new features of this model include: (i) the simulation of AR in multiple tissue compartments (i.e., brain, liver, and gonad); (ii) AR binding and its effects upon the HPG axis; and (iii) free androgen effects on brain AR concentration. As a result, this model provides a computational framework for endocrine responses of EDCs functioning through both ER and AR.
The model can be used to generate hypotheses to facilitate studies of endocrine responses in female FHMs exposed to other estrogenic EDCs in addition to $\mathrm{EE}_{2}$, or other androgenic EDCs in addition to TB. The application can be achieved by defining chemical-specific parameters, such as partition coefficients (e.g., blood to water, or tissue to blood), and binding affinities to ER and AR. Furthermore, the endpoints simulated in this study (i.e. plasma $E_{2}, T$ and VTG concentrations) are important determinants affecting egg production in FHMs. In the future, this model could be linked to an oocyte growth dynamics model developed by Li et al. (accepted). Linking these two models would build a connection between EDC effects at a molecular level with effects upon an organism, and thus a population, which is an urgent need in ecological risk assessment.

\section{Additional material}

Additional file 1: Differential equations used in the HPG axis model The file was created in Microsoft Office Word 2003. The file contains a list of the differential equations used in the HPG axis model for female fathead minnows. 
Additional file 2: U-shaped dose-response curves between TB water exposure concentrations and plasma $E_{2}, T$, and VTG concentrations in adult female FHMs. The file was created in Microsoft Office Word 2003. The file contains three plots for the non-monotonic relationship between TB water exposure concentrations and plasma $E_{2}, T$, and VTG concentrations in adult female FHMs [7].

\section{Acknowledgements}

This research was supported in part by grants from the Medical Research Foundation of Oregon [Grant \#0634 to K.W.]; U.S. Environmental Protection Agency (EPA) Science to Achieve Results (STAR) program [Cooperative Agreement \# RD-83184801-0 to N.D., K.W., M.S., and E.O.]; and by resources from the National Center for Computational Toxicology of the EPA Office of Research and Development, awarded to the Ecological Exposure Research and Ecosystem Research Divisions (National Exposure Research Laboratory) in Cincinnati, $\mathrm{OH}$ and Athens, GA, respectively, and the Mid-Continent Ecology Division (National Health and Environmental Effects Research Laboratory) in Duluth, MN.

Although the research described in this article has been funded in part by the U.S. Environmental Protection Agency, it has not been subjected to any formal EPA review and does not necessarily reflect the views of the Agency. No official endorsement should be inferred.

The authors greatly appreciate the insight and input from several individuals: Drs. Drew Ekman and Tim Collette at the U.S. EPA Ecosystem Research Division in Athens, GA, USA; Dr. Frederic Bois (INERIS, French National Institute for Industrial Environment and Risks) provided advice on how to improve model predictions of variance; and two reviewers whose comments improved the quality of this manuscript. The authors would also like to thank the Division of Environmental and Biomolecular Sytems at OHSU for their support.

\section{Author details}

'Division of Environmental and Biomolecular Systems, Oregon Health \& Science University, Beaverton, OR, 97006, USA. ²Department of Physiological Sciences and Center for Environmental and Human Toxicology, University of Florida, Gainesville, FL, 32611, USA. ${ }^{3}$ U.S. EPA, Mid-Continent Ecology Division, Duluth, MN, 55804, USA. ${ }^{4}$ Institute for the Environment, Brunel University, Uxbridge, Middlesex, UB8 3PH, UK. ${ }^{5}$ Department of Forestry and Natural Resources, Purdue University, Lafayette, IN, 47907, USA. ${ }^{6}$ Department of Animal \& Avian Sciences, University of Maryland, College Park, MD 20742 USA. ${ }^{7}$ U.S. EPA, Molecular Indicator Research Branch, Cincinnati, OH, 45268, USA. ${ }^{8}$ The McConnell Group c/o U.S. EPA NERL EERD, USA.

\section{Authors' contributions}

ZL contributed to model development, simulation, and result analysis. DLV and NDD contributed to model design, and provided experimental data. KJK, KMJ, GTA, JVB, MSS, EFO, JML, MK, and BA provided experimental data. KHW directed the research, and contributed to model development. All authors contributed to, have read, and approved the final version of the manuscript.

Received: 20 December 2010 Accepted: 5 May 2011 Published: 5 May 2011

\section{References}

1. Nagahama Y: Endocrine regulation of gametogenesis in fish. Int J Dev Biol 1994, 38:217-229.

2. Weltzien FA, Andersson E, Andersen O, Shalchian-Tabrizi K, Norberg B: The brain-pituitary-gonad axis in male teleosts, with special emphasis on flatfish (Pleuronectiformes). Comp Biochem Physiol A Mol Integr Physiol 2004 137:447-477.

3. Ankley GT, Brooks BW, Huggett DB, Sumpter JP: Repeating history: pharmaceuticals in the environment. Environ Sci Technol 2007, 41:8211-8217.

4. Ankley GT, Jensen KM, Kahl MD, Korte JJ, Makynen EA: Description and evaluation of a short-term reproduction test with the fathead minnow (Pimephales promelas). Environ Toxicol Chem 2001, 20:1276-1290.
5. Panter GH, Hutchinson TH, Hurd KS, Bamforth J, Stanley RD, Duffell S, Hargreaves A, Gimeno S, Tyler CR: Development of chronic tests for endocrine active chemicals. Part 1. An extended fish early-life stage test for oestrogenic active chemicals in the fathead minnow (Pimephales promelas). Aquat Toxicol 2006, 77:279-290.

6. Thorpe KL, Benstead R, Hutchinson TH, Tyler CR: An optimised experimental test procedure for measuring chemical effects on reproduction in the fathead minnow, Pimephales promelas. Aquat Toxicol 2007, 81:90-98.

7. Ankley GT, Jensen KM, Makynen EA, Kahl MD, Korte JJ, Hornung MW, Henry TR, Denny JS, Leino RL, Wilson VS, et al: Effects of the androgenic growth promoter 17-beta-trenbolone on fecundity and reproductive endocrinology of the fathead minnow. Environ Toxicol Chem 2003, 22:1350-1360

8. Orlando EF, Kolok AS, Binzcik GA, Gates JL, Horton MK, Lambright CS, Gray LE Jr, Soto AM, Guillette $L J$ Jr: Endocrine-disrupting effects of cattle feedlot effluent on an aquatic sentinel species, the fathead minnow. Environ Health Perspect 2004, 112:353-358.

9. Pawlowski S, van Aerle R, Tyler CR, Braunbeck T: Effects of 17alphaethinylestradiol in a fathead minnow (Pimephales promelas) gonadal recrudescence assay. Ecotoxicol Environ Saf 2004, 57:330-345.

10. Seki M, Fujishima S, Nozaka T, Maeda M, Kobayashi K: Comparison of response to 17 beta-estradiol and 17 beta-trenbolone among three small fish species. Environ Toxicol Chem 2006, 25:2742-2752.

11. Länge $R$, Hutchinson $T H$, Croudace $C P$, Siegmund $F$, Schweinfurth $H$ Hampe P, Panter GH, Sumpter JP: Effects of the synthetic estrogen 17 alpha-ethinylestradiol on the life-cycle of the fathead minnow (Pimephales promelas). Environ Toxicol Chem 2001, 20:1216-1227.

12. Ericson JF, Laenge R, Sullivan DE: Comment on "Pharmaceuticals, hormones, and other organic wastewater contaminants in U.S. streams, 1999-2000: a national reconnaissance". Environ Sci Technol 2002, 36:4005-4006, author reply 4007-4008.

13. Poirier D, Labrie C, Merand Y, Labrie F: Derivatives of ethynylestradiol with oxygenated 17 alpha-alkyl side chain: synthesis and biological activity. J Steroid Biochem 1990, 36:133-142.

14. Gale WL, Patino R, Maule AG: Interaction of xenobiotics with estrogen receptors alpha and beta and a putative plasma sex hormone-binding globulin from channel catfish (Ictalurus punctatus). Gen Comp Endocrinol 2004, 136:338-345

15. Denny JS, Tapper MA, Schmieder PK, Hornung MW, Jensen KM, Ankley GT, Henry TR: Comparison of relative binding affinities of endocrine active compounds to fathead minnow and rainbow trout estrogen receptors. Environ Toxicol Chem 2005, 24:2948.

16. Parrott JL, Blunt BR: Life-cycle exposure of fathead minnows (Pimephales promelas) to an ethinylestradiol concentration below $1 \mathrm{ng} / \mathrm{L}$ reduces egg fertilization success and demasculinizes males. Environ Toxicol 2005 20:131-141.

17. Kidd KA, Blanchfield PJ, Mills KH, Palace VP, Evans RE, Lazorchak JM, Flick RW: Collapse of a fish population after exposure to a synthetic estrogen. Proc Natl Acad Sci USA 2007, 104:8897-8901.

18. Schiffer B, Daxenberger A, Meyer $\mathrm{K}$, Meyer $\mathrm{HH}$ : The fate of trenbolone acetate and melengestrol acetate after application as growth promoters in cattle: environmental studies. Environ Health Perspect 2001, 109:1145-1151.

19. Durhan EJ, Lambright CS, Makynen EA, Lazorchak J, Hartig PC, Wilson VS, Gray LE, Ankley GT: Identification of metabolites of trenbolone acetate in androgenic runoff from a beef feedlot. Environ Health Perspect 2006, 114(Suppl 1):65-68.

20. Watanabe KH, Li Z, Kroll KJ, Villeneuve DL, Garcia-Reyero N, Orlando EF, Sepulveda MS, Collette TW, Ekman DR, Ankley GT, Denslow ND: A computational model of the hypothalamic-pituitary-gonadal axis in male fathead minnows exposed to 17alpha-ethinylestradiol and 17betaestradiol. Toxicol Sci 2009, 109:180-192.

21. Heinlein CA, Chang C: Androgen receptor (AR) coregulators: an overview. Endocr Rev 2002, 23:175-200.

22. Filby AL, Tyler CR: Molecular Characterization of Estrogen Receptors 1, 2a and $2 \mathrm{~b}$ and Their Tissue and Ontogenic Expression Profiles in Fathead Minnow (Pimephales promelas). Biol Reprod 2005, 73:648-662.

23. Villeneuve $D L$, Larkin $P$, Knoebl I, Miracle AL, Kahl MD, Jensen KM, Makynen EA, Durhan EJ, Carter BJ, Denslow ND, Ankley GT: A graphical systems model to facilitate hypothesis-driven ecotoxicogenomics 
research on the teleost brain-pituitary-gonadal axis. Environ Sci Technol 2007, 41:321-330.

24. Verrijdt G, Haelens A, Claessens F: Selective DNA recognition by the androgen receptor as a mechanism for hormone-specific regulation of gene expression. Mol Genet Metabol 2003, 78:175-185.

25. Yaron Z, Gur G, Melamed P, Rosenfeld H, Elizur A, Levavi-Sivan B: Regulation of fish gonadotropins. Int Rev Cytol 2003, 225:131-185.

26. Kumar RC, Thakur MK: Androgen receptor mRNA is inversely regulated by testosterone and estradiol in adult mouse brain. Neurobiol Aging 2004, 25:925-933.

27. Burgess $L H$, Handa RJ: Hormonal regulation of androgen receptor mRNA in the brain and anterior pituitary gland of the male rat. Brain Res Mol Brain Res 1993, 19:31-38.

28. Foradori CD, Weiser MJ, Handa RJ: Non-genomic actions of androgens. Front Neuroendocrinol 2008, 29:169-181.

29. Burnstein KL: Regulation of androgen receptor levels: implications for prostate cancer progression and therapy. J Cell Biochem 2005, 95:657-669.

30. Flouriot $G$, Pakdel F, Ducouret B, Ledrean $Y$, Valotaire $Y$ : Differential regulation of two genes implicated in fish reproduction: vitellogenin and estrogen receptor genes. Mol Reprod Dev 1997, 48:317-323.

31. Nagahama Y, Yoshikuni M, Yamashita M, Tokumoto T, Katsu Y: Regulation of oocyte growth and maturation in fish. Curr Top Dev Biol 1995, 30:103-145.

32. Kagawa H, Gen K, Okuzawa K, Tanaka H: Effects of luteinizing hormone and follicle-stimulating hormone and insulin-like growth factor-I on aromatase activity and P450 aromatase gene expression in the ovarian follicles of red seabream, Pagrus major. Biol Reprod 2003, 68:1562-1568.

33. Gale WL, Patino R, Maule AG: Interaction of xenobiotics with estrogen receptors [alpha] and [beta] and a putative plasma sex hormonebinding globulin from channel catfish (Ictalurus punctatus). Gen Comp Endocrinol 2004, 136:338-345.

34. Miguel-Queralt S, Hammond GL: Sex hormone-binding globulin in fish gills is a portal for sex steroids breached by xenobiotics. Endocrinology 2008, 149:4269-4275

35. Tollefsen KE, Ovrevik J, Stenersen J: Binding of xenoestrogens to the sex steroid-binding protein in plasma from Arctic charr (Salvelinus alpinus L.). Comp Biochem Physiol C Toxicol Pharmacol 2004, 139:127-133.

36. Teeguarden JG, Barton HA: Computational modeling of serum-binding proteins and clearance in extrapolations across life stages and species for endocrine active compounds. Risk Anal 2004, 24:751-770.

37. Laidley CW, Thomas P: Partial characterization of a sex-steroid bindingprotein in the spotted sea-trout (Cynoscion nebulosus). Biol Reprod 1994, 51:982-992.

38. Watanabe $\mathrm{KH}$, Jensen KM, Orlando EF, Ankley GT: What is normal? Biological variability in reproductive parameters of unexposed fathead minnows (Pimephales promelas). Comp Biochem Physiol C Toxicol Pharmacol 2007, 146:348-356.

39. Garcia-Reyero N, Villeneuve DL, Kroll K, Liu L, Orlando EF, Watanabe KH, Sepulveda MS, Ankley GT, Denslow ND: Expression signatures for a model androgen and antiandrogen in the fathead minnow (Pimephales promelas) ovary. Environ Sci Technol 2009, 43:2614-2619.

40. Ekman DR, Villeneuve DL, Teng Q, Ralston-Hooper KJ, Martinović-Weigelt D, Kahl MD, Jensen KM, Durhan EJ, Makynen EA, Ankley GT, Collette TW: Use of Gene Expression, Biochemical and Metabolite Profiles to Enhance Exposure and Effects Assessment of the Model Androgen 17bTrenbolone in Fish. Environ Toxicol Chem

41. Ekman DR, Teng Q, Villeneuve DL, Kahl MD, Jensen KM, Durhan EJ, Ankley GT, Collette TW: Investigating compensation and recovery of fathead minnow (Pimephales promelas) exposed to 17a-ethynylestradiol with metabolite profiling. Environ Sci Technol 2008, 42:4188-4194.

42. Lazorchak J, Armstrong B, Crane M, Ankley G, Bencic D, Biales A, Collette T, Ekman D, Flick R, Jensen $K$, et al: Results of a 21-Day Fathead Minnow (Pimphales Promelas) Fecundity Study Following Exposure to Ethinylestradiol. Proceedings of the Society of Environmental Toxicology and Chemistry North America 31st Annual Meeting; 7-11 November 2010; Portland Oregon 2010, 180.

43. Brian JV, Harris CA, Scholze M, Kortenkamp A, Booy P, Lamoree M, Pojana G, Jonkers N, Marcomini A, Sumpter JP: Evidence of estrogenic mixture effects on the reproductive performance of fish. Environ Sci Technol 2007, 41:337-344.

44. Watanabe KH, Lin H, Bart HL Jr, Martinat P, Means JC, Kunas ML, Grimm DA: Bayesian estimation of kinetic rate constants in a food web model of polycyclic aromatic hydrocarbon bioaccumulation. Ecol Model 2005, 181:229-246.

45. Lin H, Berzins DW, Myers L, George WJ, Abdelghani A, Watanabe KH: A Bayesian bioaccumulation model of polycyclic aromatic hydrocarbons in crayfish (Procambarus spp.). Environ Toxicol Chem 2004, 23:2259-2266.

46. Gelman AJ, Carlin JB, Stern HS, Rubin DB: Bayesian Data Analysis Boca Raton, FL: Chapman \& Hall/CRC; 1995.

47. Bois FY, Jackson ET, Pekari K, Smith MT: Population toxicokinetics of benzene. Environ Health Perspect 1996, 104:1405-1411.

48. Bois FY, Maszle DR: MCSim: A Monte Carlo Simulation Program. J Stat Softw 1997, 2:1-56.

49. Shoemaker J, Gayen K, Garcia-Reyero N, Perkins E, Villeneuve D, Liu L, Doyle F: Fathead minnow steroidogenesis: in silico analyses reveals tradeoffs between nominal target efficacy and robustness to cross-talk. BMC Syst Biol 2010, 4:89.

50. Ericson JF, Laenge R, Sullivan DE: Comment on "Pharmaceuticals, Hormones, and Other Organic Wastewater Contaminants in U.S. Streams, 1999-2000: A National Reconnaissance". Environ Sci Technol 2002, 36:4005-4006.

51. Ying GG, Kookana RS, Kumar A: Fate of estrogens and xenoestrogens in four sewage treatment plants with different technologies. Environ Toxicol Chem 2008, 27:87-94.

52. Desbrow C, Routledge EJ, Brighty GC, Sumpter JP, Waldock M: Identification of estrogenic chemicals in STW effluent. 1. Chemical fractionation and in vitro biological screening. Environ Sci Technol 1998, 32:1549-1558.

53. Ribeiro C, Pardal MA, Martinho F, Margalho R, Tiritan ME, Rocha E, Rocha MJ: Distribution of endocrine disruptors in the Mondego River estuary, Portugal. Environ Monit Assess 2008

54. Mylchreest E, Snajdr S, Korte JJ, Ankley GT: Comparison of ELISAs for detecting vitellogenin in the fathead minnow (Pimephales promelas). Comp Biochem Physiol C Toxicol Pharmacol 2003, 134:251-257.

55. Hoffmann JL, Torontali SP, Thomason RG, Lee DM, Brill JL, Price BB, Carr GJ, Versteeg DJ: Hepatic gene expression profiling using Genechips in zebrafish exposed to 17alpha-ethynylestradiol. Aquat Toxicol 2006, 79:233-246.

56. Filby AL, Thorpe KL, Maack G, Tyler CR: Gene expression profiles revealing the mechanisms of anti-androgen-and estrogen-induced feminization in fish. Aquat Toxicol 2007, 81:219-231.

57. Nichols JW, Fitzsimmons PN, Whiteman FW, Dawson TD, Babeu L, Juenemann J: A physiologically based toxicokinetic model for dietary uptake of hydrophobic organic compounds by fish: I. Feeding studies with 2,2',5,5'-tetrachlorobiphenyl. Toxicol Sci 2004, 77:206-218.

58. Nichols JW, McKim JM, Lien GJ, Hoffman AD, Bertelsen SL, Elonen CM: A physiologically based toxicokinetic model for dermal absorption of organic chemicals by fish. Fundam Appl Toxicol 1996, 31:229-242.

59. Robinson DE, Balter NJ, Schwartz SL: A physiologically based pharmacokinetic model for nicotine and cotinine in man. $J$ Pharmacokinet Biopharm 1992, 20:591-609.

60. Plowchalk DR, Teeguarden J: Development of a physiologically based pharmacokinetic model for estradiol in rats and humans: a biologically motivated quantitative framework for evaluating responses to estradiol and other endocrine-active compounds. Toxicol Sci 2002, 69:60-78.

61. Miwa S, Yan L, Swanson P: Localization of two gonadotropin receptors in the salmon gonad by in vitro ligand autoradiography. Biol Reprod 1994, 50:629-642.

62. Sperry TS, Thomas P: Characterization of two nuclear androgen receptors in Atlantic croaker: comparison of their biochemical properties and binding specificities. Endocrinology 1999, 140:1602-1611.

63. Murphy CA, Rose KA, Thomas P: Modeling vitellogenesis in female fish exposed to environmental stressors: predicting the effects of endocrine disturbance due to exposure to a PCB mixture and cadmium. Reprod Toxicol 2005, 19:395-409.

64. Wilson VS, Cardon MC, Gray LE, Hartig PC: Competitive binding comparison of endocrine-disrupting compounds to recombinant androgen receptor from fathead minnow, rainbow trout, and human. Environ Toxicol Chem 2007, 26:1793-1802.

65. Crim LW, Arnaud RS, Lavoie M, Labrie F: A study of LH-RH receptors in the pituitary gland of the winter flounder (Pseudopleuronectes americanus Walbaum). Gen Comp Endocrinol 1988, 69:372-377. 
66. Kashiwagi K, Dafeldecker W, Salhanick H: Purification and characterization of mitochondrial cytochrome P-450 associated with cholesterol side chain cleavage from bovine corpus luteum. J Biol Chem 1980, 255:2606-2611.

67. Shikita M, Hall PF: Cytochrome P-450 from bovine adrenocortical mitochondria: an enzyme for the side chain cleavage of cholesterol. I. Purification and properties. J Biol Chem 1973, 248:5598-5604.

68. Zhao J, Mak P, Tchoudakova A, Callard G, Chen S: Different catalytic properties and inhibitor responses of the goldfish brain and ovary aromatase isozymes. Gen Comp Endocrinol 2001, 123:180-191.

69. Barton HA, Andersen ME: A model for pharmacokinetics and physiological feedback among hormones of the testicular-pituitary axis in adult male rats: A framework for evaluating effects of endocrine active compounds. Toxicol Sci 1998, 45:174-187.

70. Artemenko IP, Zhao D, Hales DB, Hales KH, Jefcoate CR: Mitochondrial processing of newly synthesized steroidogenic acute regulatory protein (StAR), but not total StAR, mediates cholesterol transfer to cytochrome P450 side chain cleavage enzyme in adrenal cells. J Biol Chem 2001, 276:46583-46596.

71. Ge R-S, Gao H-B, Nacharaju VL, Gunsalus GL, Hardy MP: Identification of a kinetically distinct activity of $11 \beta$-hydroxysteroid dehydrogenase in rat Leydig cells. Endocrinology 1997, 138:2435-2442.

72. Schulz R, Bosma P, Zandbergen M, Van der Sanden M, Van Dijk W, Peute J, Bogerd J, Goos H: Two gonadotropin-releasing hormones in the African catfish, Clarias gariepinus: localization, pituitary receptor binding, and gonadotropin release activity. Endocrinology 1993, 133:1569-1577.

73. Bois FY, Gelman A, Jiang J, Maszle DR, Zeise L, Alexeef G: Population toxicokinetics of tetrachloroethylene. Arch Toxicol 1996, 70:347-355.

doi:10.1186/1752-0509-5-63

Cite this article as: Li et al:: A computational model of the hypothalamic - pituitary - gonadal axis in female fathead minnows (Pimephales promelas) exposed to $17 \alpha$-ethynylestradiol and $17 \beta-$ trenbolone. BMC Systems Biology 2011 5:63.

\section{Submit your next manuscript to BioMed Central and take full advantage of:}

- Convenient online submission

- Thorough peer review

- No space constraints or color figure charges

- Immediate publication on acceptance

- Inclusion in PubMed, CAS, Scopus and Google Scholar

- Research which is freely available for redistribution

Submit your manuscript at www.biomedcentral.com/submit 